\title{
WHY ARE SECURITIZATION ISSUES TRANCHED? ${ }^{1}$
}

\author{
MACIEJ FIRLA-CUCHRA \\ DEPARTMENT OF ECONOMICS \\ OXFORD UNIVERSITY
}

\author{
TIM JENKINSON \\ SAID BUSINESS SCHOOL \\ OXFORD UNIVERSITY \\ AND CEPR
}

\section{MARCH 2005}

\begin{abstract}
$\underline{\text { ABSTRACT }}$
Securitisations usually involve creating multiple tranches of a single issue with different characteristics, placed on the market as separate securities. Various theoretical explanations have been advanced to explain such tranching. This paper provides the first systematic testing of such theories using a proprietary database of over 5000 separate tranches in European securitisations raising a total of $\$ 1$ trillion. We find support for asymmetric information and market segmentation explanations for tranching and present evidence on how such different rationales influence the structuring process in practice. We also investigate the impact of tranching on the price of securities issued. For those issues where our model predicts a higher optimal number of tranches, we find that additional uniquely-rated tranches are associated with higher prices for the issue as a whole.
\end{abstract}

JEL classification: G14, G15, G32

\footnotetext{
1 Maciej Firla-Cuchra, University of Oxford, Wadham College, Oxford OX1 3PN, maciej.cuchra@economics.ox.ac.uk. Tim Jenkinson, Said Business School, University of Oxford, Park End Street, Oxford OX1 1HP, tim.jenkinson@sbs.ox.ac.uk. We would like to thank JP Morgan International in London for access to their data. We also would like to thank Colin Mayer, Alan Morrison, Tarun Ramadorai and Oren Sussman for useful comments and suggestions. We remain responsible for any errors. This research project is financially supported by a grant from the Nuffield Foundation.
} 


\section{INTRODUCTION}

Securitization has become established as an important way for financial institutions, and companies, to pool assets and sell them to investors. The importance of such asset-backed securities (ABS) within the financial industry can hardly be overestimated. Total ABS issuance within Europe has been estimated at Euro 255 billion in 2004, and has been growing rapidly in recent years. In the US the ABS market is even more developed, and represents almost $30 \%$ of the total corporate bond market. ${ }^{2}$

In securitisations, the assets themselves are typically financial obligations of third parties such as receivables, mortgages or loans, but they can also be cash flow-generating fixed assets such as aircraft or even whole businesses. At the beginning of the securitization process, a company (the "originator") decides to sell a certain group of its assets. This group of assets is pooled together and sold to an external legal entity - a special purpose vehicle (SPV). The SPV (the "issuer") buys the assets from the originator with funds raised from investors who purchase the asset backed securities issued by the SPV and backed by that pool of assets. Under the guidance of ratings agencies, the profile of expected cashflows from securitised assets is often synthetically amended and transformed by an investment bank (the "arranger") into multiple tranches. These tranches usually have different risk, duration, and other characteristics, but they are backed by the same pool of assets.

Although tranching is now a standard practice when securitisations are undertaken, the factors that determine the extent and nature of tranching remain largely unknown. This paper provides the first systematic empirical analysis of tranching. ${ }^{3}$ We employ a proprietary, and comprehensive, database - compiled by JP Morgan - of securitisations undertaken in Europe between 1987 and 2003. The sample consists of 1605 issues, and 5161 separate tranches. In total, the issues in our sample raised just over $\$ 1$ trillion - this is very close to the totals for all European securitisation issuance as reported by different sources. ${ }^{4}$ We provide some interesting stylised facts about the cross-sectional differences in the extent of tranching according to underlying asset type, and the time-series trends in the way securitisations are structured. We also use this data to test some of the theoretical predictions regarding the motivation for pooling and tranching.

At first sight, the creation of tranches is difficult to explain from the standard ModiglianiMiller perspective, since structuring additional tranches incurs transactions costs and because the creation of multiple tranches may reduce liquidity. However, as noted by Duffie (2005), there are three broad explanations: asymmetric information, market incompleteness and transactions costs. ${ }^{5}$ In this paper we lack information on transactions costs, and so focus on the predictions of the former two sets of theories.

A number of theoretical models have been proposed explaining pooling and tranching under the assumption of asymmetric information. The basic intuition of many of the models (such as Boot and Thakor (1993), Riddiough (1997), and Plantin (2004)) is that tranching may add value in the presence of heterogeneous investors with differential private information and different abilities to screen investments. For instance, by creating an essentially riskless senior tranche - attractive to those with a low ability to screen the underlying assets - the issuer is able

\footnotetext{
2 European Securitisation Forum Data Reports 2001-4; Bond Market Association for the US data (www.bondmarkets.com).

${ }^{3}$ We are not aware of any empirical paper devoted specifically to tranching. The institutional and legal background on securitisations can be found in Schwarcz (1994), one of many legal studies of the subject. The few existing empirical studies of securitisations include event-studies such as Thomas (1999, 2001) and Cuchra (2004), who aim to test the impact of securitisations on the prices of companies' debt and equity securities in the United States and Europe, respectively. Lockwood et. al. (1996) focuses on the wealth effects of securitisations for banks' investors.

${ }^{4}$ European Securitisation Forum Data Report Autumn 2004.

${ }^{5}$ There is also a growing theoretical literature on the decision to securitise in the first place, with a focus on agency issues rather than tranching (see, for example, Cuchra (2002), Iacobucci and Winter (2005) and Fang, Ong and Sing (2003)).
} 
to create a separating equilibrium and focus the returns to information acquisition on the sophisticated investors who are attracted to the more junior tranches. Such benefits from tranching have to be compared with the potential detrimental impact on liquidity.

Similarly, DeMarzo and Duffie (1999) and DeMarzo (2005) develop models in which an informed issuer trades off an information-destruction effect from pooling assets against a riskdiversification effect, and show how tranching can be optimal for large enough pools of assets. Pooling can also play a role in overcoming adverse selection problems faced by uninformed investors. Such adverse selection problems may be particularly acute given the existence of informed intermediaries who are able to purchase the high quality pools of assets, which they can then pool, repackage and sell. However, given their superior information such intermediaries face a "lemons" problem that can result in illiquidity, and a price that declines as the quantity sold increases. In this model of informed financial intermediation, pooling and tranching play a key role in allowing intermediaries to re-cycle their capital and to enhance the returns to their private information.

The second group of theoretical explanations focuses on market incompleteness. For instance, tranches might be designed to exploit specific appetites of various investor clienteles in an environment characterised by imperfect arbitrage and missing markets. Early papers on market incompleteness include Duffie and Rahi (1995) which combines spanning with asymmetric information. This is appealing because, as others have stressed, both explanations could potentially coexist with respect to different tranches created within a single issue. For example, Riddiough (1997) notes that although the creation of a senior tranche could be driven by asymmetric information, multiple junior tranches might be created to suit particular tastes of investors in order to facilitate the placement of the information-sensitive tranches in the market. More recently, Gaur, Seshadri and Subrahmanyam (2004) model a market where all assets cannot be uniquely priced: attainable claims have unique prices, but prices of unattainable claims can only be bounded. In this setup, holders of unique assets can take advantage of market incompleteness by focusing on claims that augment market spanning. The authors show that the value of a new asset can be enhanced by 'stripping away' the maximal attainable portfolio - the senior, near-riskless tranche - for which market prices are readily available, and selling the rest (the junior tranches) at the arbitrage-free prices. This suggests that market incompleteness can imply similar security design solutions as informational asymmetry.

Evidence from other markets, and from the professional literature on structuring, suggests that market incompleteness might also justify tranching if a given market segment has limited capacity and no arbitrage opportunities exist. This would imply that an arranger, when trying to place a larger, 'composite' issue with its idiosyncratic characteristics, might face a downward sloping demand curve. Such market segmentation has been well documented in other financial markets - see for example Froot and Dabora (1999), Ofek and Richardson (2000), or Wurglar and Zhuravskaya (2001). At a more informal level, market incompleteness may vary over time as investor sophistication increases.

We propose some tests of these alternative hypotheses regarding the determinants of tranching. We find evidence that the nature of tranching is developing over time in Europe, with a tendency towards more extensive tranching. This is consistent with European investors becoming more sophisticated over time, but European securitisations still remain in 2003 significantly less tranched than equivalent US issues. We also find strong evidence that larger issues tend to be tranched more extensively. Indeed, the nature of this increased tranching is interesting: issuers can create additional tranches with distinct ratings, or they can tranche within a ratings class. We find a strong relationship between issue size and intra-rating-class tranching, which suggests that market segmentation and/or downward sloping demand curve effects may indeed be significant, and dominate, at least in our sample, liquidity effects.

We also test whether asymmetric information provides an explanation for tranching. By constructing a measure of the informational-sensitivity of different asset types based on variance of observed launch spreads, we find that information asymmetry has a significant impact on the number, and type, of observed tranches. However, and consistent with the theory, this effect is 
much stronger in relation to the creation of additional tranches with distinct ratings, rather than further tranches within a particular ratings-class.

Finally, we investigate the impact of tranching on pricing. We show how the observed spreads at the time of issue relate to the way the issue is tranched. Clearly the tranching decision itself is endogenous - depending, for example, on the size of the issue, the type of assets, the extent of information asymmetry, market conditions etc. - and so we use the predictions from our econometric model of the tranching decision to investigate the relationship between structuring and pricing. We find evidence that tranching might be successful in remedying problems of market segmentation. For those issues where our model predicts a higher optimal number of tranches, we find that additional uniquely-rated tranches are associated with higher prices for the issue as a whole. This suggests that structuring is allowing issuers to exploit market factors such as greater investors' sophistication, diversification, and heterogeneous screening skills related to asymmetric information, to their advantage via tranching.

The remainder of the paper proceeds as follows. In the next section we describe the data and provide some stylised facts on the nature of securitisations and tranching. Section 3 focuses on possible market incompleteness explanations for tranching. In section 4 we develop our proxy for asymmetric information, and test whether this provides an explanation for the extent, and nature, of tranching. Section 5 then considers the relationship between tranching and pricing. Section 6 concludes.

\section{DATA DESCRIPTION AND STYLISED FACTS}

2.1 DAtaset: Our study is based on a comprehensive dataset of European securitization transactions from 1987 to 2003 used first in Cuchra (2004). The original database was compiled by JP Morgan Securitization Research Desk in London. We have cross-checked the database against the records of securitization transactions in Bloomberg and Thompson Financial. There are 1605 issues, comprising 5161 separate tranches, so on average there are 3.22 tranches per issue. Approximately $86 \%$ of all issues are floating rate issues. The dataset includes a wide range of structured finance transactions including residential mortgage-backed securities (RMBS), collateralised debt obligations (CDOs), credit card receivables and other ABS transactions. ${ }^{6}$

From the original dataset, as well as from our data gathering and cross-checking exercises, we have data on the characteristics of each tranche, including the date of the issue, the issuer, the originator, the price at issue (almost all floating rate issues are sold at par), the coupon, the launch spread measured against a given benchmark, the weighted average life until maturity, any call/put features, the rating (if rated) according to different rating agencies, plus a composite rating as reported to investors. We also have data on the type of assets being securitised (according to a standardized European classification), the size per tranche, the country of origin of assets, the currency of issue, and other details. In addition, we have some category-specific information for certain types of assets such as: market-value/cash flow or balance sheet/arbitrage specification for the CDOs.

We also have pricing data for 4090 tranches - approx. 80\% of the total. Out of 1082 tranches for which we have no pricing data, 702 are parts of CDOs and 380 are from other types of securitisations. If we eliminate all issues for which we have no pricing data for at least one of the tranches per issue, then we are left with 2518 tranches from 824 issues, approximately a half of the original set. Since we use the pricing data only in selected parts of our study, we do not dispose of the non-priced tranches up-front.

2.2 TyPES OF SECURITIZATION TRANSACTIONS: As can be seen from Table 1 we have 10 main transaction categories corresponding to the types of assets being securitised with RMBS representing the largest share of all issues ( 37\%) followed by CDOs. In terms of tranches, our

\footnotetext{
${ }^{6}$ For comparative purposes, we also use a separate dataset from the same source of 768 issues with 4388 tranches issued in the US in the single year of 2003.
} 
dataset contains 1903 RMBS securities, followed by 1730 CDOs, and 470 commercial mortgage backed securities (CMBS). Amongst the CDO tranches we have 790 'balance sheet' and 940 'arbitrage' CDOs (including 85 'super senior' tranches). ${ }^{7}$ All other types have less than 200 tranche-observations (except for unclassified).

Securities backed by various types of consumer loans are characterised by the largest average tranche size relative to issue size - they are, therefore, tranched least, not only in nominal terms, but also less than other types in relative terms. CMBS, CDO, RMBS, and the whole business (WB) securitisations are tranched most relative to their size. Since asset type might be important to us both in terms of structuring as well as information asymmetry, we also create a summary classification assigning different types of assets into five main categories: 709 mortgage issues (2373 tranches), 132 corporate issues (346), 407 CDOs (1730), 242 consumer issues (488), 19 securitisations of government assets or those of government agencies (41), and 96 unclassified or 'other' issues (183 tranches).

TABLE 1: ISSUES BY TYPE AND NUMBER OF TRANCHES PER ISSUE

\begin{tabular}{|c|c|c|c|c|c|c|c|c|c|c|c|}
\hline & \multicolumn{11}{|c|}{$\begin{array}{l}\text { Issues with the given number of tranches as percentage of all issues per type } \\
\text { Mean number of tranches per issue }\end{array}$} \\
\hline $\begin{array}{l}\text { tranches } \\
\text { per issue }\end{array}$ & CDO & CMBS & WB & RMBS & EQUIP & CONS & $\mathbf{S A}$ & AUTO & OTHER & CARDS & TOTAL \\
\hline 1 & $16.0 \%$ & $15.0 \%$ & $21.6 \%$ & $20.5 \%$ & $24.4 \%$ & $25.0 \%$ & $36.8 \%$ & $27.8 \%$ & $53.8 \%$ & $58.1 \%$ & $24.6 \%$ \\
\hline 2 & $9.8 \%$ & $13.3 \%$ & $15.7 \%$ & $26.5 \%$ & $41.5 \%$ & $30.0 \%$ & $36.8 \%$ & $55.7 \%$ & $25.5 \%$ & $17.6 \%$ & $22.6 \%$ \\
\hline 3 & $18.9 \%$ & $17.7 \%$ & $19.6 \%$ & $19.6 \%$ & $14.6 \%$ & $33.8 \%$ & $10.5 \%$ & $13.9 \%$ & $9.0 \%$ & $20.3 \%$ & $18.6 \%$ \\
\hline 4 & $16.5 \%$ & $12.4 \%$ & $21.6 \%$ & $13.4 \%$ & $12.2 \%$ & $7.5 \%$ & $5.3 \%$ & $1.3 \%$ & $6.9 \%$ & $2.7 \%$ & $12.3 \%$ \\
\hline 5 & $13.5 \%$ & $13.3 \%$ & $3.9 \%$ & $10.2 \%$ & $7.3 \%$ & $3.8 \%$ & $10.5 \%$ & $1.3 \%$ & $2.1 \%$ & $1.4 \%$ & $9.0 \%$ \\
\hline 6 & $8.6 \%$ & $10.6 \%$ & $7.8 \%$ & $3.9 \%$ & & & & & $1.4 \%$ & & $4.9 \%$ \\
\hline 7 & $5.2 \%$ & $10.6 \%$ & $3.9 \%$ & $2.0 \%$ & & & & & $1.4 \%$ & & $3.1 \%$ \\
\hline 8 & $3.9 \%$ & $1.8 \%$ & $2.0 \%$ & $0.8 \%$ & & & & & & & $1.5 \%$ \\
\hline 9 & $2.9 \%$ & $1.8 \%$ & & $0.2 \%$ & & & & & & & $0.9 \%$ \\
\hline $10+$ & $4.7 \%$ & $3.5 \%$ & $3.9 \%$ & $2.9 \%$ & & & & & & & $2.6 \%$ \\
\hline total issues & 407 & 113 & 51 & 596 & 441 & 80 & 19 & 79 & 145 & 74 & 1605 \\
\hline
\end{tabular}

Note: Classification by type is according to the European classification of securitisations: 'CDO' are collateralised debt obligations; 'CMBS' are commercial mortgage-backed securities; 'WB' are whole-business securitisations; 'RMBS' are residential mortgage-backed securities, 'Equip' are securitisations of equipment assets, 'Cons' are securitisations of consumer assets other than auto-loans, credit cards or mortgages; 'SA' are securitisations of government or public agencies' assets or obligations; 'Auto' are securitisations of auto-loans; 'Cards' are credit-card securitisations.

The nominal value of each tranche in the currency of issue is converted into US dollars at the closing exchange rate on the date of issue, as reported by Datastream. Table 2 reports summary statistics on issue size. Securitisations of sovereign and public agency assets and obligations are largest overall across different types with a mean issue size in excess of US\$2 billion, followed by whole-business (corporate) securitisations, CDO, CMBS and RMBS. The average size of a tranche is $\$ 196$ million, although there is significant cross-sectional variation. For instance, the two largest tranches in our sample are $\$ 6.8$ billion each, being part of the same AAA-rated issue from Cyber-Val in 1997. The third largest is the \$5 billion issue by the Spanish government to collateralize its nuclear payment obligations. Out of 38 tranches in the sample that are larger than $\$ 2$ billion, 26 are CDO tranches. The bottom $10 \%$ of all tranches are $\$ 9.4$ million or less in size and the top $10 \%$ are $\$ 520$ million or more.

\footnotetext{
${ }^{7}$ A super senior tranche might be kept by the selling US bank (European banks sell its risk via a CDS to another bank, typically from the US). Risk-free assets such as super-senior tranches require only $20 \%$ of capital according to US regulations (instead of normal 100\%) of which $8 \%$ is immobilized in both cases. Source: SG ABS Research Report 2000.
} 
TABLE 2: DISTRIBUTION OF TRANSACTION SIZES BY TYPE

\begin{tabular}{|l|c|c|c|c|c|c|c|c|c|c|c|}
\hline & \multicolumn{9}{|c|}{ Type of the issue } \\
\hline & SA & WB & CDO & RMBS & CMBS & Cards & Equip & Auto & Cons & Other & Total \\
\hline $\begin{array}{l}\text { mean size of issue } \\
\text { (million current US\$) }\end{array}$ & 2029 & 828 & 727 & 659 & 594 & 571 & 420 & 405 & 377 & 362 & 630 \\
\hline $\begin{array}{l}\text { standard deviation } \\
\text { (size, million current US\$) }\end{array}$ & 1842 & 785 & 1277 & 849 & 722 & 223 & 331 & 302 & 317 & 508 & 923 \\
\hline $\begin{array}{l}\text { skewness } \\
\text { (size) }\end{array}$ & 1.07 & 1.37 & 5.41 & 4.05 & 4.35 & 0.41 & 1.43 & 1.56 & 2.72 & 5.77 & 5.55 \\
\hline
\end{tabular}

See Table 1 for explanation of the classification.

2.3 Tranching AND RATINGS: Ratings reveal substantial information about securities and casual evidence suggests that they are closely linked with particular groups of investors. Tranches in our dataset are rated by several credit rating agencies: $70 \%$ of all tranches are rated by Moody's, 65\% are rated by S\&P, and $55 \%$ are rated by Fitch. Almost $14 \%$ of all tranches are not rated by any of the agencies. The original database also features a 'composite' rating, drawing on the separate ratings of different agencies. This composite rating is reported in the following broad categories, without any refinements: AAA, AA, A, BBB, BB and B. In our sample 1831 securities are rated AAA, 622 are rated AA, 957 are rated A, 784 are rated BBB, and 240 are rated $\mathrm{BB}$ or less. There are only six securities rated single-B and only one security rated below B, according to the composite rating. From Cuchra (2004) we adopt another set of ratings - the 'extended Moody's ratings'. This has the advantage of preserving all refinements while incorporating ratings from other agencies for issues not rated by Moody's and hence being as comprehensive as the composite rating. For comparison, Ammer and Clinton (2004) use a composite credit rating constructed from Moody's and S\&P's ratings "using the average based on the standard mapping between their respective rating scales". Their dataset excludes securities that are rated below BBB3 or less than US\$ 25 million in size. In comparison, 32\% of tranches in our dataset are less than US\$25 million.

Since tranching is often said to be about carving out a riskless tranche, we are interested in the relative size of senior tranches. As can be seen in Table 3, transactions based on 'consumer' obligations (as per our general classification) other than mortgages are characterised by the largest AAA-tranches relative to the size of issue. This might in part be due to the low risk of the entire pool. However, consumer loans other than cards and auto loans also exhibit large senior tranches, relative to their issue size, despite being rather risky overall. On the other hand, AAA-rated tranches are relatively small in the case of corporate assets, such as wholebusiness securitisations and commercial property. The same picture emerges when we take into account all senior tranches, not just AAA-rated, since for some issues an AAA-rated tranche is never created. This picture is to a lesser degree reflected by the relative sizes of the most junior tranches. 
TABLE 3: TRANCHING AND RATINGS

\begin{tabular}{|c|c|c|c|c|c|c|c|c|c|c|c|}
\hline & \multicolumn{11}{|c|}{ issue type } \\
\hline & Cards & Auto & SA & Equip & RMBS & CMBS & Other & Cons & WB & CDO & Total \\
\hline $\begin{array}{l}\% \text { of all issues with at least } 1 \\
\text { AAA-rated tranche }\end{array}$ & $95 \%$ & $87 \%$ & $47 \%$ & $83 \%$ & $80 \%$ & $74 \%$ & $57 \%$ & $68 \%$ & $37 \%$ & $66 \%$ & $73 \%$ \\
\hline $\begin{array}{l}\text { average size of all top-rated } \\
\text { tranches \% of the issue* }\end{array}$ & $96 \%$ & $96 \%$ & $99 \%$ & $90 \%$ & $90 \%$ & $72 \%$ & $91 \%$ & $90 \%$ & $73 \%$ & $55 \%$ & $81 \%$ \\
\hline $\begin{array}{l}\text { average size of the bottom-rated } \\
\text { tranche } \% \text { of the issue** }\end{array}$ & $6 \%$ & $5 \%$ & $8 \%$ & $11 \%$ & $5 \%$ & $11 \%$ & $15 \%$ & $8 \%$ & $18 \%$ & $21 \%$ & $12 \%$ \\
\hline $\begin{array}{l}\text { average issue rating (AAA=6) } \\
\text { weighted by tranche size }\end{array}$ & 5.7 & 5.3 & 5.1 & 4.9 & 4.8 & 4.8 & 4.7 & 4.5 & 4 & 3.2 & 4.4 \\
\hline most senior tranches \# & 80 & 93 & 39 & 59 & 990 & 183 & 188 & 101 & 105 & 664 & 2502 \\
\hline most junior tranches \# & 30 & 51 & 1 & 26 & 502 & 111 & 51 & 54 & 44 & 415 & 1285 \\
\hline $\begin{array}{l}\text { average \# of most senior tranches } \\
\text { per issue }\end{array}$ & 1.08 & 1.18 & 2.05 & 1.44 & 1.66 & 1.62 & 1.30 & 1.26 & 2.06 & 1.63 & 1.56 \\
\hline $\begin{array}{l}\text { mean size of AAA-rated tranches } \\
\text { (where present) \% of the issue }\end{array}$ & $89 \%$ & $80 \%$ & $42 \%$ & $64 \%$ & $53 \%$ & $43 \%$ & $69 \%$ & $69 \%$ & $30 \%$ & $35 \%$ & $52 \%$ \\
\hline $\begin{array}{l}\text { mean size of BBB and below } \\
\text { tranches \% of the issue }\end{array}$ & $15 \%$ & $45 \%$ & - & $28 \%$ & $22 \%$ & $13 \%$ & $43 \%$ & $37 \%$ & $28 \%$ & $23 \%$ & $23 \%$ \\
\hline
\end{tabular}

Note: *Excluding all issues with no tranches rated. **Bottom-rated tranches excluded tranches classified at the same time as top-rated: e.g. in the case of all single-tranche issues. Rating is the composite rating of all ratings assigned by rating agencies to the particular tranche. Top tranches include all tranches with the highest rating in the issue (can be multiple); bottom tranches include all tranches with the lowest rating in the issue (can be multiple) but exclude single-tranche cases). See Table 1 for explanation of the classification.

Although there is no consistent relationship between the number of tranches and the size of issue, it is clear in the extremes: issues over $\$ 1$ billion in size have, on average, over 5 tranches, issues of $\$ 100$ million or less have barely 2 tranches. As shown in the Table 4, the share of issues tranched into 1-4 securities varies significantly according to issue size, but there is a significantly greater number of single-tranche issues among very small transactions. Very large issues differ considerably in the extent of tranching: for example, 22\% of all issues of $\$ 1$ billion or more have only 1 or 2 tranches, although a similar proportion (24\%) have 7 or more tranches.

\section{TABLE 4: ISSUES BY SIZE AND THE NUMBER OF TRANCHES}

\begin{tabular}{|c|c|c|c|c|}
\hline tranches & 1 & 2 & 3 & 4 \\
\hline & $<$ US\$100m & US\$100-500m & US\$500-1000m & $>$ US\$1000m \\
\hline 1 & $79(46 \%)$ & $216(25 \%)$ & $69(21 \%)$ & $31(13 \%)$ \\
\hline 2 & $38(22 \%)$ & $232(27 \%)$ & $71(21 \%)$ & $22(9 \%)$ \\
\hline 3 & $30(18 \%)$ & $176(21 \%)$ & $61(18 \%)$ & $31(13 \%)$ \\
\hline 4 & $14(8 \%)$ & $93(11 \%)$ & $52(16 \%)$ & $38(16 \%)$ \\
\hline 5 & 5 & 59 & 42 & 23 \\
\hline 6 & 3 & 33 & 19 & 58 \\
\hline $7+$ & 2 & 47 & 21 & $\mathbf{5 . 0 7}$ \\
\hline Mean & $\mathbf{2 . 0 9}$ & $\mathbf{2 . 8 9}$ & $\mathbf{3 . 2 8}$ & $\mathbf{2 4 1}$ \\
\hline Total & $\mathbf{1 7 1}$ & $\mathbf{8 5 8}$ & $\mathbf{3 3 5}$ & \\
\hline
\end{tabular}

Note: Size of each tranche is calculated in US\$ by converting the size of each tranche in the currency of issue at the exchange rate from the date of issue; issue size is the sum of all tranches of a given issue in the dataset.

2.4 EXPECTED MATURITY, PREPAYMENT AND MARKET CHARACTERISTICS: Among other important characteristics differentiating tranches in securitisation transactions, the expected maturity or 'life' is reported by practitioners to be crucial. This is because nominal maturity is typically meaningless in securitisations because of different prepayment schedules as well as embedded options. ${ }^{8}$ The 'weighted average life' or 'WAL' is in fact a catch-all variable reported in the prospectus with the corresponding prepayment assumptions (where applicable), any

\footnotetext{
${ }^{8}$ Fabozzi (2000).
} 
possible step-ups (of the coupon), and any embedded options, if present. As can be seen from Table 5, the number of tranches per issue does not vary greatly with the expected average life of each security. Still, the average expected weighted average life of each issue (understood as the mean of the weighted average expected lives of tranches per issue) rises with 'WAL' for all but the longest expected maturity tranches.

TABLE 5: EXPECTED MATURITY AND TRANCHE SIZE

\begin{tabular}{|c|c|c|c|c|c|c|}
\hline & & \multicolumn{5}{|c|}{ 'life’categories } \\
\hline \multicolumn{2}{|c|}{ Size-categories } & 1 & 2 & 3 & 4 & . \\
\hline 1 & $<$ US\$100 & $\begin{array}{l}1.78 \\
(18)\end{array}$ & $\begin{array}{l}2.88 \\
(26)\end{array}$ & $\begin{array}{l}2.73 \\
(11)\end{array}$ & $\begin{array}{l}2.18 \\
(17)\end{array}$ & $\begin{array}{l}1.86 \\
(99)\end{array}$ \\
\hline 2 & US\$100-500m & $\begin{array}{c}2.50 \\
(175)\end{array}$ & $\begin{array}{c}2.98 \\
(167)\end{array}$ & $\begin{array}{l}3.67 \\
(64)\end{array}$ & $\begin{array}{l}2.75 \\
(81)\end{array}$ & $\begin{array}{c}2.94 \\
(371)\end{array}$ \\
\hline 3 & US\$500-1000m & $\begin{array}{l}3.18 \\
(85)\end{array}$ & $\begin{array}{c}3.42 \\
(103)\end{array}$ & $\begin{array}{l}3.48 \\
(29)\end{array}$ & $\begin{array}{l}2.71 \\
(35)\end{array}$ & $\begin{array}{l}3.37 \\
(83)\end{array}$ \\
\hline 4 & >US\$1bn & $\begin{array}{l}5.96 \\
(55)\end{array}$ & $\begin{array}{l}5.70 \\
(56)\end{array}$ & $\begin{array}{l}4.90 \\
(20)\end{array}$ & $\begin{array}{l}4.88 \\
(26)\end{array}$ & $\begin{array}{l}4.17 \\
(84)\end{array}$ \\
\hline & Total & (333) & $(352)$ & (124) & (159) & $(637$ \\
\hline
\end{tabular}

Note: Size of each tranche is calculated in US\$ by converting the size of each tranche in the currency of issue at the exchange rate from the date of issue; issue size is the sum of all tranches of a given issue in the dataset; 'life' is the expected average life of each tranche given prepayment assumptions as calculated in the prospectuses of the issue of which the particular tranches if a part of.

Nevertheless differentiation by WAL seems less significant than might be expected. We have a sub-sample of 968 issues with 3257 tranches, for which we know the expected life of each tranche. For 2392 or $73 \%$ of all tranches in this sub-sample, there exists at least one tranche with an identical expected life in the same issue. Therefore, only 0.89 out of the average of 3.36 tranches per issue has a unique expected life in that issue. Expected life least differentiates CDO, CMBS and RMBS issues. Similarly, we observe a significantly greater number of tranches than the number of unique rating groups of tranches per issue. In other words, some tranches have the same rating as other tranches, which is surprising given the typical assumption that tranches are differentiated by rating. Sovereign, agency, whole-business and CDO issues are least differentiated by rating: e.g. only $69 \%$ of tranching in the whole-business securitisations is characterised by differentiated credit ratings.

Given the popularity of 'clientele effects' as a practitioner explanation for structuring, we are naturally interested in differentiation by target markets. 3231 of all our tranches are designed to be placed in one of the European 'public' markets, 1803 in the European 'private' market, and 127 are issued as public securities in the US backed by European assets. Most of the transactions in the dataset are classified as 'European' on the basis of the origin of assets, but 9 securities are classified as 'international', 119 securities are classified as 'European' and for 242 securities no country has been specified. ${ }^{9}$ Overall, we have 27 countries represented with 14 out of those with more than 20 observations. United Kingdom represents the greatest share with 460 securities, followed by Italy with 164, Spain with 101, France with 97, Netherlands with 75, US with 69, Germany with 61, and Portugal with 41. In terms of the currency of issue, we have 2933 securities denominated in euro and 1209 denominated in British pounds - both of which have an identical average tranche size of $\$ 183$ million - as well as 446 securities denominated in US dollars (average size of $\$ 273$ million) and 118 originally denominated in French francs (\$380 million); other currencies are represented by less than 100 securities each.

\footnotetext{
${ }^{9}$ There are also some assets in the dataset which come from non-European originators, but are placed in Europe.
} 


\section{TRANCHING, SOPHISTICATION AND MARKET INCOMPLETENESS}

3.1 Tranching AND INVESTORS' SOPHISTICATION: The first set of hypotheses we would like to test concerns markets' and investors' sophistication in relation to structuring. For example Plantin (2004), among others, predicts that increasing investors sophistication should be associated with more tranching and greater differentiation among the constituent parts. Plantin's model suggests that issuers in particular should be interested in tranching securities backed by high quality, info-sensitive assets to attract classes of sophisticated investors. Issuers might also want to tranche securities backed by assets that are not very info-sensitive if investors' sophistication is sufficiently high and if there is a sufficient number of sophisticated investors. This implies that tranching of less info-sensitive assets should be increasing with investors' sophistication. The author also shows that multiple tranches might be optimal in equilibrium with several different 'classes' of investors as long as there is a sufficient gradation in screening skills - the key measure of investors' sophistication. ${ }^{10}$

We start with the most obvious measure of the level and sophistication of tranching - the number of tranches per issue - a choice variable for the arranger assumed to maximize value. Since our data covers virtually the entire history of securitisations in Europe, we would expect investors to develop greater sophistication in line with market development throughout time. The strong market development over time is confirmed by the simple observation of a significant and steady increase in the number of securitization transactions (issues) year by year, as can be seen from Figure 1.

FIGURE 1: DEVELOPMENT OF TRANCHING IN EUROPE SINCE 1987

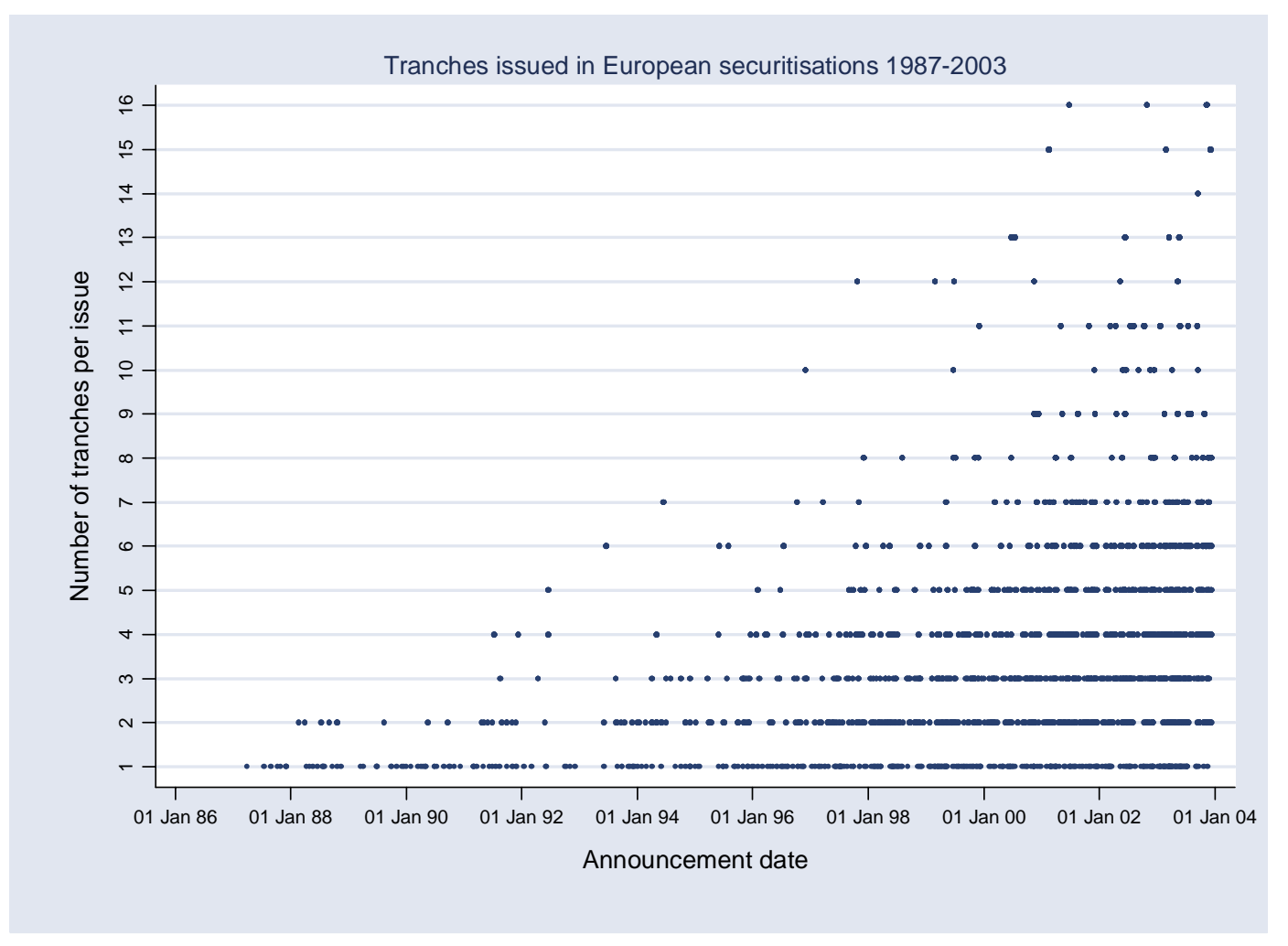

Given that the number of transactions rises every year since 1987, it is natural, therefore, to proxy investors' sophistication with the index of the year of issue starting at the year of the first transaction in our dataset (1987). Our test is therefore whether we could observe a higher

\footnotetext{
${ }^{10}$ One of his findings is that the average sophistication of the successful bidder for a given tranche decreases with its seniority.
} 
number of tranches to be associated with a larger market as developing over time. Any alternative measure of investors' sophistication unrelated to the time dimension the potential problem of explaining how different securitization transactions, coming to the market at the same time (year), might differ in terms of the level of sophistication among investors. As an alternative test, we look at the comparison of the US and European markets. It is also widely reported that the US securitization market is more mature and more sophisticated than the European one. We would therefore expect to see the number of tranches per issue in the US market to exceed that in Europe for the same types of assets.

TABLE 6: ISSUES, TRANCHES AND COLLATERAL TYPES ACROSS TIME

\begin{tabular}{|l|c|c|c|c|c|c|c|c|c|c|c|c|c|c|c|c|c|}
\hline & $\mathbf{1 9 8 7}$ & $\mathbf{1 9 8 8}$ & $\mathbf{1 9 8 9}$ & $\mathbf{1 9 9 0}$ & $\mathbf{1 9 9 1}$ & $\mathbf{1 9 9 2}$ & $\mathbf{1 9 9 3}$ & $\mathbf{1 9 9 4}$ & $\mathbf{1 9 9 5}$ & $\mathbf{1 9 9 6}$ & $\mathbf{1 9 9 7}$ & $\mathbf{1 9 9 8}$ & $\mathbf{1 9 9 9}$ & $\mathbf{2 0 0 0}$ & $\mathbf{2 0 0 1}$ & $\mathbf{2 0 0 2}$ & $\mathbf{2 0 0 3}$ \\
\hline $\begin{array}{l}\text { Average size of } \\
\text { a tranche }\end{array}$ & 185 & 181 & 328 & 258 & $\mathbf{1 7 1}$ & 158 & 153 & 149 & 123 & 311 & 299 & 178 & 168 & 137 & 145 & 149 & 286 \\
\hline $\begin{array}{l}\text { Number of } \\
\text { issues per year }\end{array}$ & 8 & 17 & 12 & 17 & 26 & 12 & 17 & 34 & 44 & 54 & 84 & 102 & 159 & 177 & 252 & 261 & 329 \\
\hline Agency (\%) & & & & & & & & & & & & & 1 & 2 & 3 & 1 & 1 \\
\hline CDO (\%) & & & & 6 & & & & & 20 & 12 & 17 & 10 & 17 & 23 & 34 & 32 & 39 \\
\hline Consumer (\%) & & & & 29 & 19 & 50 & 29 & 15 & 12 & 31 & 20 & 24 & 20 & 12 & 12 & 15 & 9 \\
\hline Corporate (\%) & & & & & & 8 & 6 & 15 & 7 & 7 & 5 & 6 & 10 & 11 & 8 & 9 & 8 \\
\hline Mortgage (\%) & 100 & 100 & 100 & 65 & 81 & 42 & 65 & 70 & 59 & 43 & 46 & 47 & 42 & 42 & 35 & 40 & 41 \\
\hline Other (\%) & & & & & & & & & 2 & 7 & 12 & 13 & 10 & 10 & 8 & 3 & 2 \\
\hline
\end{tabular}

Note: Average size of a tranche is reported in millions of US dollars (converted into US dollars at the current exchange rate if denominated in another currency).

As can be seen from the Table 6, there is a clear trend of an increasing number of tranches per issue over time. This trend does not seem to be explained by the typedecomposition of issues. For example, the share of mortgages, one of the most 'tranched' categories, has fallen steadily throughout the period, but the average number of tranches per mortgage securitization has increased steadily almost every year throughout the period. The positive relationship between investors' sophistication and the optimal number of tranches is confirmed by comparing the European and the US samples. As can be seen from the Table 7, the average number of tranches per issue for transactions announced in 2003 is greater in the US than in the entire European sample for almost every asset-type. For some asset types, the tranching averages in the US securitisations exceed those in Europe by as much as $100 \%$, despite the fact that the average issue size is almost identical: US\$659million vs. US\$630 million. In fact, for the single year of 2003, the average size of the European issue (US\$1127 million) is almost twice the size of the US average.

\section{TABLE 7: TRANChING IN EUROPE AND THE UNITED STATES}

\begin{tabular}{|c|c|c|c|c|c|c|c|c|c|c|c|}
\hline \multirow[b]{2}{*}{ Sample / type } & \multicolumn{11}{|c|}{ Number of tranches per issue, standard deviation and the number of issues for different categories of assets } \\
\hline & CDO & CMBS & WB & RMBS & EQUIP & CONS & SA & AUTO & OTHER & CARDS & TOTAL \\
\hline Euro sample & 407 & 113 & 51 & 596 & 41 & 80 & 19 & $\overline{79}$ & 145 & 74 & 1605 \\
\hline Euro mean & 4.25 & 4.16 & 3.51 & 3.19 & 2.37 & 2.35 & 2.16 & 1.94 & 1.88 & 1.73 & 3.22 \\
\hline Stand dev & 2.65 & 2.41 & 2.36 & 2.32 & 1.2 & 1.06 & 1.3 & 0.82 & 1.28 & 1.02 & 2.33 \\
\hline 2003 sample & 129 & 24 & 13 & 110 & 5 & 6 & 3 & 9 & 20 & 10 & 329 \\
\hline 2003 mean & 4.10 & 4.5 & 2.92 & 4.53 & 2.8 & 3.17 & 3.67 & 2.56 & 1.55 & 2.5 & 3.93 \\
\hline Stand dev & 2.66 & 2.52 & 1.98 & 3.01 & 1.64 & 1.33 & 1.53 & 0.73 & 0.83 & 1.58 & 2.69 \\
\hline US type & CDO & & & $\begin{array}{l}\text { HOMEQ } \\
\end{array}$ & EQUIP & STUDL & & AUTO & I OTHER & CARDS & TOTAL \\
\hline US 2003 & 135 & & & 384 & 16 & 31 & & 92 & 33 & 95 & 786 \\
\hline US mean & 5.8 & & & 6.88 & 5.56 & 6.03 & & 4.74 & 2.64 & 1.72 & 5.58 \\
\hline
\end{tabular}

Note: See Table 1 for explanation of the classification. The US sample is for the year 2003 only: 'HOMEQ' are home equity loans and other mortgages; 'STUDL' are student loans. In the US sample there are no separate categories representing CMBS, whole-business or sovereign/agency securitisations. 
To test this more rigorously we run an ordered logit regression to explain the number of tranches per transaction with the year index and several controls for all 1605 issues in our dataset. The advantage of the ordered logit methodology in this context is that it allows for purely normative ordering without any assumptions about the relative size of each 'step' between two consecutive, discrete realizations of the dependent variable. However, the number of tranches per issue clearly contains more information than any categorization based on groups of issues with progressively higher number of tranches. This information might be captured by OLS but not by ordered logit. Therefore, we report equivalent results using OLS for comparison.

Our controls include a measure of the type of collateral. We are also interested in seeing if there is asset-specific innovation so we include interaction controls of year index with type dummies. We also control for the size of issue and for the issue 'life': the size-weighted, average expected maturity of an issue across all tranches as explained in the previous section. This is important since these controls might be related to tranching by channels other than market sophistication, which we investigate further below. We also note that our sample is reduced by approx. 1/3 (as explained in Section 2) when controlling for the weighted average life.

Our results, presented in Table 8, show that the year index as a proxy for investors' sophistication has a significant and positive effect on the number of tranches after controlling for the type of assets. It also remains significant and of similar magnitude after we conduct robustness checks by adding additional controls including the size of an issue. The year index remains significant, but weaker when we include the weighted average life of an issue. This would suggest that there are more longer-dated issues in recent years than before and longer expected maturities make tranching more beneficial, perhaps because they add an extra dimension for splitting securities. Finally, in order to check that we are not influenced by the quality of assets, we also control for the weighted average launch spread per issue (the weighted sum of launch spreads of each tranche). Although average issue spread has a positive and significant coefficient, the impact of the asymmetry index remains almost unchanged.

To check our results further, we bring in two other proxies for investors' sophistication in specific markets rather than across time. This has the advantage that we could simultaneously test different dimensions of sophistication. As a first proxy we include a dummy for European issues that are placed on the US market - we have 127 such tranches in our dataset. The dummy is significant at the $10 \%$ level, but becomes stronger and significant at $5 \%$ level when we drop controls for the expected life of the issue and the average launch spread. This is likely to be due to the fact that our sample of issues placed in the US is significantly reduced with those controls. Given these problems, we would like to test for an alternative, cross-sectional proxy of investors sophistication. As a second proxy, therefore, we use the level of sophistication of each market across Europe determined by the ranking of countries according to the overall number of securitisation issues originated each state. We then regress the number of tranches on the set of all controls, the year index, and the country ranking. The coefficient on the country variable is strong and significant. Clearly, developed securitisation markets with many originators and sophisticated investors are characterised by a substantially higher optimal number of tranches per issue than smaller, developing securitisation markets. We note that although the year effect is now weaker, it remains significant at $10 \%$ level, but of the same magnitude as before.

Overall, evidence broadly supports the conclusions of asymmetric information theories that greater sophistication of investors should be associated with greater benefits to tranching and structuring. On average, we predict that it takes circa 8 years to increase the optimal number of tranches per issue by 1 . This result could be combined with the comparable data for the US market in 2003 implying that the European securitisation market is approx. 13 years behind the US in investors' sophistication and market development. Nevertheless, the gap might be smaller if we account for the greater share of securitisations involving highly idiosyncratic assets in Europe, which might decrease the optimal number of tranches per issue. 
TABLE 8: INITIAL DETERMINANTS OF TRANCHING

Dependent variable in all regressions is the number of tranches per issue. Each observation represents a single issue. Independent variables: 'log of issue size' is the log of the sum of sizes of all tranches expressed millions of US\$ converted from the issue currency at the FX rate at the date of issue; 'year index' is the year of issue; 'issue life' is the weighted average (by size) of component tranches' expected maturities in years since launch; 'average launch' is the weighted average spread of component tranches per issue at launch over LIBOR; 'us public' is a dummy =1 if an issue is placed on the US public market (there are no issues placed in the US private market); 'issues per country' is the total number of all securitisation issues per country; 'auto' is a dummy $=1$ if the issue type is auto-loans or auto-leases (= 0 otherwise); 'cards' is a dummy $=1$ if the issue is backed by revenues from credit or debit card payments ( $=0$ otherwise); 'rmbs' is a dummy $=1$ if the issue is backed by residential mortgages (= 0 otherwise); 'cmbs' is a dummy $=1$ if the issue is backed by commercial mortgage ( $=0$ otherwise); 'cdo' is a dummy $=1$ if athe issue type is a collateralized debt obligation (= 0 otherwise); 'whole business' is a dummy $=1$ if the issue is a whole business securitisation; 'consumer' is a dummy =1 if the issue type is backed by consumer loans other than consumer loans classified in other categories; 'other' is a dummy $=1$ if the issue is not otherwise classified; 'equipment' is a dummy $=1$ if the issue type is backed by corporate equipment assets; a dummy for securitisations of sovereign and public agencies' assets is omitted. The OLS regression includes a constant. Z-statistics in ordered logit regressions and t-statistics in the OLS regression, calculated from the Huber-White robust errors, are reported in brackets. Pseudo $\mathrm{R}^{2}$ is reported for ordered logit regressions; adjusted $\mathrm{R}^{2}$ is reported for the OLS regression.

\begin{tabular}{|c|c|c|c|c|c|c|c|}
\hline & \multicolumn{7}{|c|}{ Coefficients (z-statistics for ordered logit; t-statistics for OLS) } \\
\hline regression & I & II & III & IV & $\mathrm{V}$ & VI & VII \\
\hline model & ologit & OLS & ologit & ologit & ologit & ologit & ologit \\
\hline constant & - & $\begin{array}{l}-4.81 \\
(-8.35) \\
\end{array}$ & - & - & - & - & - \\
\hline $\begin{array}{l}\text { year index } \\
\text { (sophistication proxy I) }\end{array}$ & $\begin{array}{c}\mathbf{0 . 1 7} \\
(11.32) \\
\end{array}$ & $\begin{array}{c}\mathbf{0 . 1 2} \\
(7.92)\end{array}$ & $\begin{array}{c}\mathbf{0 . 0 9} \\
(3.00)\end{array}$ & $\begin{array}{c}\mathbf{0 . 0 8} \\
(2.72) \\
\end{array}$ & $\begin{array}{c}\mathbf{0 . 0 8} \\
(2.65) \\
\end{array}$ & $\begin{array}{c}\mathbf{0 . 1 7} \\
(11.18) \\
\end{array}$ & $\begin{array}{c}0.07 \\
(1.70)\end{array}$ \\
\hline auto & $\begin{array}{l}1.05 \\
(2.30)\end{array}$ & $\begin{array}{l}1.01 \\
(2.01)\end{array}$ & $\begin{array}{c}1.18 \\
(2.41)\end{array}$ & $\begin{array}{c}1.24 \\
(2.53) \\
\end{array}$ & $\begin{array}{l}1.22 \\
(2.48)\end{array}$ & $\begin{array}{c}1.03 \\
(2.26) \\
\end{array}$ & $\begin{array}{c}\mathbf{1 . 3 8} \\
(2.72)\end{array}$ \\
\hline cards & $\begin{array}{c}0.25 \\
(0.54) \\
\end{array}$ & $\begin{array}{c}0.46 \\
(0.92)\end{array}$ & $\begin{array}{c}0.40 \\
(0.50) \\
\end{array}$ & $\begin{array}{c}0.45 \\
(0.90) \\
\end{array}$ & $\begin{array}{c}0.43 \\
(0.85) \\
\end{array}$ & $\begin{array}{c}0.24 \\
(0.51)\end{array}$ & $\begin{array}{c}0.45 \\
(0.81)\end{array}$ \\
\hline cdo & $\begin{array}{l}\mathbf{3 . 0 5} \\
(7.09)\end{array}$ & $\begin{array}{l}\mathbf{3 . 0 6} \\
(6.61)\end{array}$ & $\begin{array}{l}4.60 \\
(9.49)\end{array}$ & $\begin{array}{c}4.53 \\
(9.32) \\
\end{array}$ & $\begin{array}{c}\mathbf{4 . 5 1} \\
(9.28)\end{array}$ & $\begin{array}{c}\mathbf{3 . 0 3} \\
(7.05) \\
\end{array}$ & $\begin{array}{c}4.86 \\
(8.22)\end{array}$ \\
\hline cmbs & $\begin{array}{l}\mathbf{3 . 0 6} \\
(6.81) \\
\end{array}$ & $\begin{array}{c}2.97 \\
(6.08) \\
\end{array}$ & $\begin{array}{c}4.39 \\
(8.84) \\
\end{array}$ & $\begin{array}{c}4.29 \\
(8.61) \\
\end{array}$ & $\begin{array}{c}4.28 \\
(8.58) \\
\end{array}$ & $\begin{array}{c}\mathbf{3 . 0 4} \\
(6.78) \\
\end{array}$ & $\begin{array}{c}3.44 \\
(6.46) \\
\end{array}$ \\
\hline consumer & $\begin{array}{c}1.75 \\
(3.84)\end{array}$ & $\begin{array}{c}\mathbf{1 . 5 1} \\
(2.99)\end{array}$ & $\begin{array}{c}2.40 \\
(4.78) \\
\end{array}$ & $\begin{array}{c}\mathbf{2 . 4 5} \\
(4.86) \\
\end{array}$ & $\begin{array}{c}2.42 \\
(4.80)\end{array}$ & $\begin{array}{c}1.72 \\
(3.79) \\
\end{array}$ & $\begin{array}{c}2.42 \\
(4.58)\end{array}$ \\
\hline equipment & $\begin{array}{c}\mathbf{1 . 6 4} \\
(3.28)\end{array}$ & $\begin{array}{c}1.45 \\
(2.66)\end{array}$ & $\begin{array}{l}1.29 \\
(2.22)\end{array}$ & $\begin{array}{c}1.29 \\
(2.21) \\
\end{array}$ & $\begin{array}{c}1.26 \\
(2.17)\end{array}$ & $\begin{array}{c}1.62 \\
(3.24) \\
\end{array}$ & $\begin{array}{l}1.30 \\
(2.17)\end{array}$ \\
\hline other & $\begin{array}{c}0.79 \\
(1.76)\end{array}$ & $\begin{array}{c}1.17 \\
(2.42)\end{array}$ & $\begin{array}{c}\mathbf{1 . 6 6} \\
(3.35) \\
\end{array}$ & $\begin{array}{c}1.46 \\
(2.91) \\
\end{array}$ & $\begin{array}{c}1.43 \\
(2.85) \\
\end{array}$ & $\begin{array}{c}0.77 \\
(1.71) \\
\end{array}$ & $\begin{array}{c}1.27 \\
(2.42) \\
\end{array}$ \\
\hline rmbs & $\begin{array}{c}2.25 \\
(5.35) \\
\end{array}$ & $\begin{array}{c}2.14 \\
(4.66)\end{array}$ & $\begin{array}{c}2.77 \\
(6.16)\end{array}$ & $\begin{array}{c}\mathbf{2 . 8 1} \\
(6.23) \\
\end{array}$ & $\begin{array}{c}\mathbf{2 . 7 6} \\
(6.11) \\
\end{array}$ & $\begin{array}{c}2.21 \\
(5.24) \\
\end{array}$ & $\begin{array}{c}\mathbf{2 . 6 1} \\
(5.64) \\
\end{array}$ \\
\hline whole business & $\begin{array}{c}\mathbf{2 . 0 6} \\
(4.25)\end{array}$ & $\begin{array}{c}\mathbf{2 . 0 0} \\
(3.78)\end{array}$ & $\begin{array}{c}\mathbf{3 . 6 4} \\
(6.66) \\
\end{array}$ & $\begin{array}{c}\mathbf{3 . 2 2} \\
(5.70) \\
\end{array}$ & $\begin{array}{c}3.21 \\
(5.68) \\
\end{array}$ & $\begin{array}{c}\mathbf{2 . 0 5} \\
(4.23) \\
\end{array}$ & $\begin{array}{c}\mathbf{2 . 5 3} \\
(4.24) \\
\end{array}$ \\
\hline $\log$ of issue size & $\begin{array}{c}\mathbf{0 . 6 4} \\
(12.52) \\
\end{array}$ & $\begin{array}{c}\mathbf{0 . 7 2} \\
(14.78)\end{array}$ & $\begin{array}{c}\mathbf{0 . 9 6} \\
(12.71) \\
\end{array}$ & $\begin{array}{c}\mathbf{1 . 0 4} \\
(12.90)\end{array}$ & $\begin{array}{c}\mathbf{1 . 0 1} \\
(12.53)\end{array}$ & $\begin{array}{c}\mathbf{0 . 6 3} \\
(12.21) \\
\end{array}$ & $\begin{array}{c}\mathbf{1 . 1 0} \\
(11.23)\end{array}$ \\
\hline issue life & & & $\begin{array}{c}\mathbf{- 0 . 0 8} \\
(-5.40)\end{array}$ & $\begin{array}{c}\mathbf{- 0 . 0 9} \\
(-5.57)\end{array}$ & $\begin{array}{c}\mathbf{- 0 . 0 9} \\
(-5.50)\end{array}$ & & $\begin{array}{c}-\mathbf{- 0 . 1 0} \\
(-5.60)\end{array}$ \\
\hline average launch & & & & $\begin{array}{l}\mathbf{0 . 0 0 4} \\
(2.91) \\
\end{array}$ & $\begin{array}{l}\mathbf{0 . 0 0 4} \\
(2.84) \\
\end{array}$ & & $\begin{array}{l}\mathbf{0 . 0 0 6} \\
(3.32) \\
\end{array}$ \\
\hline $\begin{array}{l}\text { us public } \\
\text { (sophistication proxy II) }\end{array}$ & & & & & $\begin{array}{c}0.88 \\
(1.70)\end{array}$ & $\begin{array}{c}1.23 \\
(2.43)\end{array}$ & \\
\hline $\begin{array}{l}\text { issues per country } \\
\text { (sophistication proxy III) }\end{array}$ & & & & & & & $\begin{array}{l}\mathbf{0 . 0 0 1} \\
(6.56)\end{array}$ \\
\hline issue type & all & all & all & all & all & all & all \\
\hline pseudo- $\mathrm{R}^{2} /$ adj. $\mathrm{R}^{2}$ & 10.9 & 29.7 & 13.8 & 14.0 & 14.1 & 11.0 & 13.5 \\
\hline no. of observations & 1605 & 1605 & 968 & 968 & 968 & 1605 & 729 \\
\hline
\end{tabular}

3.2 MARKET INCOMPLETENESS AND SEGMENTATION: According to information asymmetry theories, tranches should be differentiated by seniority. To offer an example, a CDO issue might be tranched into a senior AAA-rated tranche and a junior BB-rated tranche. If there is sufficient differentiation among investors, then the junior tranche might be tranched further into a BBBrated tranche and the so-called 'kitchen-sink', subordinated junior tranche, which might B-rated or not rated at all. However, theories of tranching based on informational asymmetry might have difficulties explaining why a senior AAA-rated tranche would be tranched further into two, paripassu AAA-rated tranches with different expected maturities or denominated in another currency. 
In general, our dataset strongly supports the hypothesis that tranches should be differentiated by rating: on average, there are 2.07 differently rated groups of tranches per issue. ${ }^{11}$ However, since there are 3.22 tranches per issue overall, $36 \%$ of tranching is unrelated to the differentiation by rating. ${ }^{12}$ In Table 9 we show how such differentiation varies according to asset type. The results are not affected by single-tranche issues: If we eliminate all such issues, which cannot be differentiated by rating by default (representing $24.6 \%$ of all issues), the average overall number of tranches rises to 3.94 per issue of which over $35 \%$ cannot be differentiated by rating. This simple evidence strongly points at the conclusion that market segmentation, market incompleteness and liquidity factors might play an important role in tranching.

TABLE 9: TRANCHES, RATINGS AND EXPECTED MATURITIES

\begin{tabular}{|l|c|c|c|c|c|c|c|c|c|c|c|}
\hline & \multicolumn{9}{|c|}{ issue type } \\
\hline & SA & WB & CDO & CMBS & RMBS & Equip & Other & Cons & Auto & Cards & Total \\
\hline $\begin{array}{l}\text { \% of tranches per issue } \\
\text { differentiated by rating }\end{array}$ & $51 \%$ & $56 \%$ & $57 \%$ & $71 \%$ & $64 \%$ & $69 \%$ & $76 \%$ & $78 \%$ & $82 \%$ & $93 \%$ & $\mathbf{6 4 \%}$ \\
\hline $\begin{array}{l}\% \text { of tranches per issue } \\
\text { differentiated by expected life }\end{array}$ & $98 \%$ & $81 \%$ & $53 \%$ & $61 \%$ & $75 \%$ & $80 \%$ & $88 \%$ & $83 \%$ & $87 \%$ & $77 \%$ & $\mathbf{7 1 \%}$ \\
\hline
\end{tabular}

Note: \% of tranches per issue differentiated by rating = average number of identically rated groups of tranches per issue divided by the number of tranches per issue in a given asset category. \% of tranches per issue differentiated by expected life $=$ average number of groups of tranches per issue with the same expected life divided by the number of tranches per issue in a given asset category. See Table 1 for explanation of the classification.

The incomplete markets argument for tranching is presented in a model by Gaur, Seshadri and Subrahmanyam (2004) who solve a value maximization problem of the price of securities sold in the market and backed by multiple originators' assets, for different levels of pooling and tranching. ${ }^{13}$ The optimal regions for tranching and pooling are dependent on the relative unit prices at which originators sell securities to the intermediary and are nonmonotonic. In this context tranching could be particularly attractive at times of lower market liquidity associated with imperfect arbitrage and missing markets.

Similarly, the problem of market segmentation implies that splitting larger issues into several, more refined tranches should be particularly important for large issues, junior classes, and in difficult market conditions. By dividing the issue, the arranger could enlarge the investors' base and avoid a detrimental effect of quantity on price. But these 'market incompleteness' and 'market segmentation' hypotheses alone would imply that optimal tranching consists of splitting each issue into a large number of tranches of different characteristics. This might not be optimal since tranching is costly due to high legal, regulatory, servicing and rating agency costs in the case of multiple groups of creditors with different cash flow rights - see for example Schwarcz (1994), who reports that securitisations are rarely cost effective for transactions of US\$50-100 million or less. ${ }^{14}$ Moreover, tranching is likely to be costly in liquidity terms.

Combining these effects tranching could represent a trade-off between: (i) the benefits of tapping different market segments while avoiding a downward sloping demand curve in each segment for large issues, and (ii) the ex-post liquidity and transaction costs of finely tranched transactions. Taken together, 'market segmentation' and 'liquidity premium' hypotheses jointly imply a positive relation between size of an issue and the number of tranches resulting in a

\footnotetext{
${ }^{11}$ Almost all issues in our sample have external or internal enhancement based on a first-loss 'equity' tranche retained by the issuer or, equivalently, external first-loss insurance from a mono-line insurer.

${ }^{12}$ In order to determine rating groups we use the 'extended Moody’s ratings' (as explained in the previous section) instead of composite ratings in order to capture all refinements.

${ }^{13}$ This is 'extremal' nature of the security design: extremal securities cannot be formed as convex combinations of others and have maximal market span (maximal feasible portfolio payoffs).

${ }^{14} 3.4 \%$ of the issues in our sample are less than US\$50 million in size and $10.2 \%$ of the issues are less than US $\$ 100$ million.
} 
relatively stable average size of a tranche. Since liquidity and market segmentation should be associated with the issue size, we can use it as a proxy for the post-issue liquidity and the severity of market segmentation. Small issues are expected to be tranched less in order to preserve post-issue liquidity, whereas large issues might be expected to be tranched more if they face segmented markets. Jointly, these theories predict a strong, positive relationship between size and the number of tranches as well as a relatively stable average nominal size of a tranche.

We find strong evidence in support of these factors determining the optimal number of tranches. The results of the ordered logit regressions in Table 8 show that the number of tranches decreases as the issue size falls. Since this relationship is predicted jointly by the liquidity and market segmentation hypotheses as well as by significant transaction costs of tranching, the importance of this effect can be easily explained.

\section{TRANCHING AND ASYMMETRIC INFORMATION}

4.1 INFORMATION ASYMMETRY, ASSET DIFFRENTIATION AND TRANCHING: One of the mOSt important conclusions from the security design literature is that the optimum level of tranching is predicted to be higher for info-sensitive assets. ${ }^{15}$ For example, the effect of tranching in the Boot and Thakor (1993) model is to reduce the variance of pricing (true value assessment) per tranche. Since issuers' revenues are positively correlated with the information sensitivity of the junior tranches and tranching is costly, the issuers with highly information-sensitive assets should tranche more. If tranching is unable to establish the minimum threshold of private information concentration in a junior tranche, it might not be worth pursuing. Similarly, Riddiough (1997) model implies that multiple-tranched issues should be typical of more infosensitive assets since the latter offer greater benefits to compensate for higher transaction costs.

Also DeMarzo (2005) shows that combination of pooling and tranching is optimal when private information is common to all assets, but information risks are idiosyncratic (assetspecific), since this combination best allows for the creation of a riskless tranche. He asserts that tranching should be particularly attractive when private information (screening ability) is poolspecific and characteristic of the type of the asset. This "may explain the tendency not to combine types of underlying assets (e.g. mortgages and corporate bonds), since for these different asset classes the private information is likely to be uncorrelated". ${ }^{16}$ It follows that if types of assets are differentiated by the degree of information sensitivity, those where private information is important can benefit more from tranching. Also, since gains from tranching are enhanced if the pool has lower residual risk, issues with better collateral should be tranched more. Moreover, the DeMarzo and Duffie (1999) model implies that information sensitive portions of the cashflows should be sold rather than retained if the degree of asymmetric information is not too severe. This implies that more sophisticated structuring might be needed to place assets with more asymmetric information if the issuer wants to avoid the lemonsproblem discount.

In order to test these hypotheses, we proxy the informational asymmetry of assets being securitised by ranking 10 categories of asset types according to the variance of launch spreads within each type/rating group at the time of issue. The variance in spreads has been linked to information asymmetry before: For example, Bernardo and Cornell (1997) conclude that significant variance in MBS spreads is related to private information; similar evidence is provided by Wallace (2001).

Since a simple variance of launch spreads across all tranches of a given type might be related to the number of tranches by construction (because structuring an issue with a higher

\footnotetext{
${ }^{15}$ This might be due to technical complexity of some assets, as in the case of elaborate prepayment models, or a significant impact of the private information factor on price. DeMarzo (2001), for example, links such information sensitivity with the type of assets being securitised - a critical determinant given the fact that structuring features are generally shared across different transactions of the same type.

${ }^{16}$ Ibid. p. 19.
} 
number of tranches might result in greater differentiation of tranches by price) we calculate the average variances of launch spreads in each rating/type group, as reported in the Table 10, and then calculate the weighted mean of means for each asset class (equivalent to the 'within' estimator). This approach implicitly assumes that price implications of any tranche characteristics beyond a given 'rating/type' group can only be understood by sophisticated investors and are related to private information. In effect, this implies that unsophisticated investors cannot fully understand why such issues are priced differently. ${ }^{17}$ We also want to check our results for the averages of variances of weighted average tranche spreads per issue (issue spreads) per asset type across time since tranching by itself might add to the information asymmetry.

\section{TABLE 10: TYPE OF ASSETS AND THE INFORMATION ASYMMETRY INDEX}

The table reports a mean launch spread in basis points for each composite rating-type of collateral (standard deviations are reported in brackets). Mean st. dev. shows the average standard deviation of launch spreads for each type for collateral - the mean across different rating categories. 'All' reports the mean launch spread and the standard deviation of all tranches of a given type. See Table 1 for explanation of the classification. The 'Corp' category includes all types of securities backed by corporate collateral except for CDOs and CMBS; the 'Con' category includes all types of securities backed by consumers’ collateral except for RMBS.

\begin{tabular}{|c|c|c|c|c|c|c|c|c|c|c|c|c|}
\hline Rating & CDO & CMBS & WB & RMBS & EQUIP & CONS & SA & AUTO & CARDS & $\begin{array}{c}\text { OTHE } \\
\mathbf{R}\end{array}$ & CORP & CON \\
\hline $\mathbf{A A A}$ & $\begin{array}{c}45 \\
(48)\end{array}$ & $\begin{array}{c}51 \\
(\mathbf{3 4})\end{array}$ & $\begin{array}{c}57 \\
(23)\end{array}$ & $\begin{array}{c}28 \\
(\mathbf{1 7})\end{array}$ & $\begin{array}{c}35 \\
(15)\end{array}$ & $\begin{array}{c}32 \\
(13)\end{array}$ & $\begin{array}{c}19 \\
(10)\end{array}$ & $\begin{array}{c}29 \\
(12)\end{array}$ & $\begin{array}{c}22 \\
(12)\end{array}$ & $\begin{array}{c}51 \\
(38)\end{array}$ & $\begin{array}{c}47 \\
(25)\end{array}$ & $\begin{array}{c}28 \\
\text { (13) }\end{array}$ \\
\hline $\mathbf{A A}$ & $\begin{array}{c}74 \\
(40)\end{array}$ & $\begin{array}{c}73 \\
\mathbf{( 3 7 )} \\
\end{array}$ & $\begin{array}{l}74 \\
(-)\end{array}$ & $\begin{array}{c}53 \\
(\mathbf{2 5})\end{array}$ & $\begin{array}{c}59 \\
(37)\end{array}$ & $\begin{array}{c}66 \\
(28)\end{array}$ & $\begin{array}{c}44 \\
(35)\end{array}$ & $\begin{array}{l}42 \\
(4)\end{array}$ & - & $\begin{array}{c}78 \\
(34)\end{array}$ & $\begin{array}{c}61 \\
(\mathbf{2 5})\end{array}$ & $\begin{array}{c}63 \\
\mathbf{( 2 7 )} \\
\end{array}$ \\
\hline $\mathbf{A}$ & $\begin{array}{l}135 \\
(75)\end{array}$ & $\begin{array}{l}109 \\
\text { (51) }\end{array}$ & $\begin{array}{l}113 \\
(30)\end{array}$ & $\begin{array}{c}80 \\
(33)\end{array}$ & $\begin{array}{c}74 \\
(27)\end{array}$ & $\begin{array}{c}77 \\
(27)\end{array}$ & $\begin{array}{c}44 \\
(36)\end{array}$ & $\begin{array}{c}64 \\
(24)\end{array}$ & $\begin{array}{c}58 \\
(18)\end{array}$ & $\begin{array}{l}132 \\
(53)\end{array}$ & $\begin{array}{l}103 \\
(32)\end{array}$ & $\begin{array}{c}68 \\
(\mathbf{2 5})\end{array}$ \\
\hline BBB & $\begin{array}{c}247 \\
(130)\end{array}$ & $\begin{array}{l}207 \\
(\mathbf{6 5})\end{array}$ & $\begin{array}{l}250 \\
(63)\end{array}$ & $\begin{array}{l}162 \\
(58)\end{array}$ & $\begin{array}{c}197 \\
(116)\end{array}$ & $\begin{array}{l}167 \\
(59)\end{array}$ & - & $\begin{array}{l}152 \\
\text { (33) }\end{array}$ & $\begin{array}{l}145 \\
(51)\end{array}$ & $\begin{array}{c}260 \\
(103)\end{array}$ & $\begin{array}{l}258 \\
(\mathbf{8 3})\end{array}$ & $\begin{array}{l}154 \\
\mathbf{( 5 2 )}\end{array}$ \\
\hline BB & $\begin{array}{c}481 \\
(203)\end{array}$ & $\begin{array}{c}424 \\
\text { (171) }\end{array}$ & $\begin{array}{l}586 \\
(64)\end{array}$ & $\begin{array}{c}367 \\
(\mathbf{1 0 3}) \\
\end{array}$ & $\begin{array}{c}170 \\
(184)\end{array}$ & $\begin{array}{c}400 \\
(-)\end{array}$ & - & - & - & $\begin{array}{c}527 \\
(156) \\
\end{array}$ & $\begin{array}{c}516 \\
(\mathbf{1 8 1}) \\
\end{array}$ & $\begin{array}{c}400 \\
(-)\end{array}$ \\
\hline NR & $\begin{array}{c}250 \\
(331) \\
\end{array}$ & $\begin{array}{c}169 \\
\mathbf{( 1 5 4 )} \\
\end{array}$ & $\begin{array}{c}163 \\
(110) \\
\end{array}$ & $\begin{array}{c}85 \\
(\mathbf{9 8 )} \\
\end{array}$ & $\begin{array}{c}96 \\
(68) \\
\end{array}$ & $\begin{array}{c}38 \\
(13) \\
\end{array}$ & - & $\begin{array}{c}88 \\
(46) \\
\end{array}$ & - & $\begin{array}{c}204 \\
(137) \\
\end{array}$ & $\begin{array}{l}111 \\
(\mathbf{7 6}) \\
\end{array}$ & $\begin{array}{r}66 \\
\mathbf{( 4 3 )} \\
\end{array}$ \\
\hline $\begin{array}{c}\text { Mean } \\
\text { st. dev. }\end{array}$ & (138) & (85) & (58) & (56) & (75) & (28) & (27) & (24) & (27) & (87) & (70) & (32) \\
\hline All & $\begin{array}{c}151 \\
(\mathbf{1 7 1})\end{array}$ & $\begin{array}{c}126 \\
(\mathbf{1 2 0})\end{array}$ & $\begin{array}{c}165 \\
(\mathbf{1 3 5})\end{array}$ & $\begin{array}{c}75 \\
\mathbf{( 8 0 )}\end{array}$ & $\begin{array}{c}69 \\
\text { (70) }\end{array}$ & $\begin{array}{c}70 \\
\mathbf{( 5 8 )}\end{array}$ & $\begin{array}{c}31 \\
(\mathbf{2 8})\end{array}$ & $\begin{array}{c}49 \\
(36)\end{array}$ & $\begin{array}{c}53 \\
(\mathbf{5 2})\end{array}$ & $\begin{array}{c}121 \\
(\mathbf{1 1 9})\end{array}$ & $\begin{array}{c}129 \\
(\mathbf{1 2 5})\end{array}$ & $\begin{array}{c}58 \\
\mathbf{( 5 0 )}\end{array}$ \\
\hline
\end{tabular}

Table 10 reports our findings: in general, it is clear that asset pools with corporate obligors, such as CMBS, CDOs or whole-business securitisations are characterized by the higher variance of spreads than pools of consumer loans, such as credit cards or auto-loans. This might be expected because consumer loans are typically more numerous in any asset pool and hence their individual variances might be better diversified away, while being more homogenous and less idiosyncratic than the industry- or company-specific corporate securitisations. This important role of pooling based on the 'risk diversification effect' was pointed out before by DeMarzo (2001). We also note that mortgage-backed securities have relatively high variance vis-à-vis other assets, as reported in other studies, which might be due to pool-specific prepayment risks.

To test this interpretation further, we make two additional comparisons: since pools of mortgages are likely to differ from other assets, we compare CMBS with RMBS issues. As can be seen from Table 10, the former have a higher variance for every rating group. Similarly, if we group corporate and consumer assets together, defined by the type of an obligor, we observe that the former are characterized by higher variances across all but one rating category. This confirms our interpretation of the patterns across 10 different types. Also, we note that the 'other' category

\footnotetext{
${ }^{17}$ It could be argued that the 'information asymmetry frontier' is located elsewhere: On one hand, unsophisticated investors might not fully understand the implications of differences in the type of assets and only consider the rating as a 'catch-all' variable. On the other hand, they might be able to price more complex characteristics of each tranche, such as the payment structure or the prepayment risks. Here, we take the middle ground by assuming that the rating-type combination captures most of the significant information understood by unsophisticated investors. We have tested the implications of constructing more refined buckets with other characteristics as extra dimensions, but these do not change our ordering in any substantial way.
} 
is characterized by high variance, as expected, due to the non-standard nature of these transactions. These observations are confirmed by other studies. For example, Hu and Cantor (2003) present important evidence regarding ratings in structured finance transactions in the US between 1983 and 2002: consistent with our findings, they show that CDO ratings are more volatile than for any other asset category; moreover, corporate securitisations are characterised by only $81.49 \%$ share of issues with unchanged ratings vis-à-vis $87.66 \%$ for all structured finance. $^{18}$

We now turn to testing the information asymmetry hypothesis by using the ordered logit and OLS models used in the previous section. We control for investor's sophistication (proxied by the year index) and the log of issue size to proxy for the effects of post-issue liquidity and severity of market segmentation on the optimal number of tranches. The asset-type dummies are now replaced by our information asymmetry index taking values 1 to 10 across asset types. The results, presented in Table 11, strongly indicate that information asymmetry exhibits a positive and significant relation to the number of tranches, as predicted by the asymmetric information literature. A move by 3-4 asset categories towards the most info-sensitive end of the spectrum is associated with an optimal increase in the number of tranches per issue by 1 . This effect remains significant after we control for the weighted average life, as reported in the table below. Our conclusions are even more significant given that the construction of the private information index might be producing a bias against our results. This is because assets that are tranched more might have a lower variance of launch spreads per tranche, purely because of more refined tranching. This would imply that our measure of information asymmetry would actually underestimate it for the more finely tranched assets.

4.2 ASYMmetric INFORMATION AND THE QUALITY OF ASSETS: Asymmetric information theories of tranching directly or indirectly predict that tranching should be particularly beneficial for better quality assets. For example, Plantin (2004) gives the example of the balance sheet- and arbitrage-type CDOs, which are driven by 'immunization' and 'sensitization', respectively: tranching should be particularly attractive for high quality assets in case of the former and when investors are sufficiently sophisticated in case of the latter. ${ }^{19}$ Boot and Thakor (1993) predict that issuers with better quality of collateral might tranche more despite the fact that low-quality issuers would also tranche in equilibrium. They show that with more than two types of issuers, those with the highest quality of collateral might split securities into 3 tranches ranked by seniority, if the gain is greater than the loss due to reduction in liquidity. ${ }^{20}$ However, market segmentation and liquidity hypotheses imply the opposite: segmentation should be less severe for better quality assets, as the market for high quality issues, such as AAA-rated bonds, is generally seen as very deep. High quality assets might also be easier to place due to greater liquidity.

\footnotetext{
${ }^{18}$ In comparison, the share of securities with unchanged ratings (throughout their lives) is 83.35\% for CDO only and $79.84 \%$ for the unclassified category, where the latter do not typically fit any standard pricing models and might require significant expertise to be assessed on a case-by-case basis. This in contrast with RMBS, which are characterized by a high $89.18 \%$ share of unchanged ratings.

${ }^{19}$ Other papers in financial contracting literature take up the issue of the optimal number of creditors and the number of securities issued. For example, Bolton and Scharfstein (1996) conclude that firms with a higher quality of assets should issue multiple securities to multiple creditors. A lower number of creditors is optimal if 'asset complementarity' - the degree to which assets are worth more together than apart - is high, and when the degree to which they can be redeployed is also high. These effects act in opposite direction so the overall effect is ambiguous, but in securitisations 'asset complementarity' could be linked to large pools of many individual loans, which are highly complimentary in terms of benefits from managing the entire pool, while redeployment could be easier for individual automobiles or houses than for corporate assets. This would imply that CDOs (where pools are less significant than for mortgages and assets cannot be easily redeployed) should be tranched less, but this is not confirmed by the data.

${ }^{20}$ The authors assert that, in general, multiple financial claims can be derived in equilibrium according to this logic.
} 


\section{TABLE 11: TRANCHING, ASYMMETRIC INFORMATION AND MARKET INCOMPLETENESS}



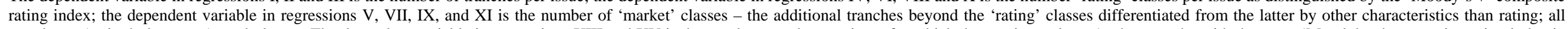

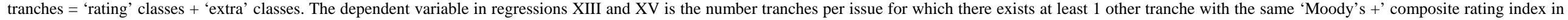

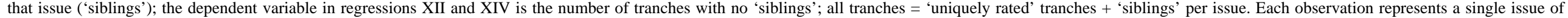

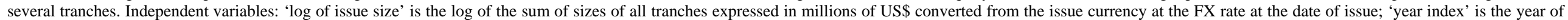

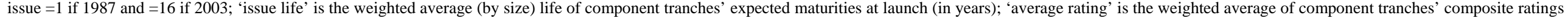

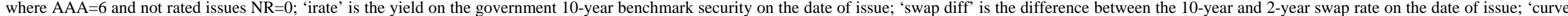

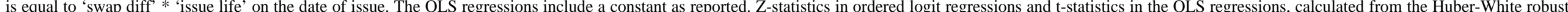
errors, are reported in brackets. Pseudo $\mathrm{R}^{2}$ is reported for ordered logit regressions; adjusted $\mathrm{R}^{2}$ is reported for the OLS regressions.

\begin{tabular}{|c|c|c|c|c|c|c|c|c|c|c|c|c|c|c|c|}
\hline dependent variable & $\begin{array}{c}\text { all } \\
\text { tranches }\end{array}$ & $\begin{array}{c}\text { all } \\
\text { tranches }\end{array}$ & $\begin{array}{c}\text { all } \\
\text { tranches }\end{array}$ & $\begin{array}{c}\text { rating } \\
\text { classes }\end{array}$ & $\begin{array}{l}\text { market } \\
\text { classes }\end{array}$ & $\begin{array}{c}\text { rating } \\
\text { classes }\end{array}$ & $\begin{array}{l}\text { market } \\
\text { classes }\end{array}$ & $\begin{array}{c}\text { rating } \\
\text { classes }\end{array}$ & $\begin{array}{l}\text { market } \\
\text { classes }\end{array}$ & $\begin{array}{l}\text { rating } \\
\text { classes }\end{array}$ & $\begin{array}{l}\text { market } \\
\text { classes }\end{array}$ & $\begin{array}{c}\text { uniquely } \\
\text { rated }\end{array}$ & $\begin{array}{c}\text { rating } \\
\text { siblings }\end{array}$ & $\begin{array}{c}\text { uniquely } \\
\text { rated }\end{array}$ & $\begin{array}{c}\text { rating } \\
\text { siblings }\end{array}$ \\
\hline regression & I & II & III & IV & $\mathrm{V}$ & VI & VII & VIII & IX & $\mathrm{X}$ & $\mathrm{XI}$ & XII & XIII & XIV & $\mathrm{XV}$ \\
\hline model & ologit & ologit & ologit & ologit & ologit & ologit & ologit & OLS & OLS & ologit & ologit & ologit & ologit & OLS & OLS \\
\hline info-asymmetry index & $\begin{array}{c}\mathbf{0 . 2 0 3} \\
(11.42)\end{array}$ & $\begin{array}{c}\mathbf{0 . 3 5 8} \\
(14.26)\end{array}$ & $\begin{array}{c}\mathbf{0 . 3 4 7} \\
(13.29)\end{array}$ & $\begin{array}{c}\mathbf{0 . 3 4 2} \\
(12.65)\end{array}$ & $\begin{array}{c}\mathbf{0 . 2 1 8} \\
(7.53)\end{array}$ & $\begin{array}{c}\mathbf{0 . 3 1 3} \\
(10.94)\end{array}$ & $\begin{array}{c}\mathbf{0 . 2 1 7} \\
(6.79)\end{array}$ & - & - & - & - & $\begin{array}{l}\mathbf{0 . 1 4 9} \\
(5.56) \\
\end{array}$ & $\begin{array}{c}\mathbf{0 . 2 2 1} \\
(6.65)\end{array}$ & - & - \\
\hline $\log$ of issue size & $\begin{array}{c}\mathbf{0 . 6 6 8} \\
(13.50)\end{array}$ & $\begin{array}{c}\mathbf{0 . 9 5 7} \\
(13.38)\end{array}$ & $\begin{array}{c}\mathbf{0 . 9 7 2} \\
(13.43)\end{array}$ & $\begin{array}{l}\mathbf{0 . 4 8 8} \\
(7.26)\end{array}$ & $\begin{array}{c}\mathbf{1 . 0 1 6} \\
(12.31)\end{array}$ & $\begin{array}{l}\mathbf{0 . 5 6 7} \\
(7.56)\end{array}$ & $\begin{array}{c}\mathbf{1 . 0 0 0} \\
(11.09)\end{array}$ & $\begin{array}{l}\mathbf{0 . 2 7 9} \\
(6.89)\end{array}$ & $\begin{array}{c}\mathbf{0 . 8 1 5} \\
(13.05)\end{array}$ & $\begin{array}{l}\mathbf{0 . 6 2 4} \\
(7.69)\end{array}$ & $\begin{array}{l}\mathbf{0 . 9 2 7} \\
(9.71)\end{array}$ & $\begin{array}{l}0.054 \\
(0.71)\end{array}$ & $\begin{array}{c}\mathbf{1 . 0 2 7} \\
(10.84)\end{array}$ & $\begin{array}{l}0.029 \\
(0.54)\end{array}$ & $\begin{array}{l}\mathbf{1 . 0 6 6} \\
(8.33)\end{array}$ \\
\hline year index & $\begin{array}{c}\mathbf{0 . 1 5 0} \\
(10.05) \\
\end{array}$ & $\begin{array}{l}\mathbf{0 . 0 8 7} \\
(3.00) \\
\end{array}$ & $\begin{array}{l}\mathbf{0 . 0 8 8} \\
(3.04) \\
\end{array}$ & $\begin{array}{r}\mathbf{0 . 1 5 4} \\
(5.17) \\
\end{array}$ & $\begin{array}{c}-0.057 \\
(1.71)\end{array}$ & \begin{tabular}{|l|}
$\mathbf{0 . 1 7 0}$ \\
$(3.06)$ \\
\end{tabular} & $\begin{array}{l}-0.051 \\
(0.79) \\
\end{array}$ & \begin{tabular}{|l|}
$\mathbf{0 . 1 1 5}$ \\
$(3.79)$ \\
\end{tabular} & $\begin{array}{l}-0.022 \\
(0.49) \\
\end{array}$ & $\begin{array}{l}\mathbf{0 . 1 9 6} \\
(3.47) \\
\end{array}$ & $\begin{array}{l}-0.028 \\
(0.43) \\
\end{array}$ & \begin{tabular}{|l|}
$\mathbf{0 . 1 5 4}$ \\
$(2.85)$ \\
\end{tabular} & $\begin{array}{l}-0.045 \\
(0.69) \\
\end{array}$ & $\begin{array}{l}\mathbf{0 . 1 2 0} \\
(3.80)\end{array}$ & $\begin{array}{r}-0.027 \\
(0.50) \\
\end{array}$ \\
\hline issue life & & $\begin{array}{l}\mathbf{- 0 . 0 8 3} \\
(6.06)\end{array}$ & $\begin{array}{l}\mathbf{- 0 . 0 8 5} \\
(6.19)\end{array}$ & $\begin{array}{r}\mathbf{- 0 . 1 0 3} \\
(7.23)\end{array}$ & $\begin{array}{l}-0.019 \\
(1.26)\end{array}$ & $\begin{array}{l}\mathbf{- 0 . 1 2 8} \\
(6.82) \\
\end{array}$ & $\begin{array}{l}\mathbf{0 . 0 4 8} \\
(2.57)\end{array}$ & $\begin{array}{l}-\mathbf{- 0 . 0 5 1} \\
(-5.28)\end{array}$ & $\begin{array}{l}\mathbf{0 . 0 5 6} \\
(3.72)\end{array}$ & $\begin{array}{l}\mathbf{- 0 . 1 0 7} \\
(5.08)\end{array}$ & $\begin{array}{l}\mathbf{0 . 0 4 8} \\
(2.44)\end{array}$ & $\begin{array}{l}\mathbf{- 0 . 1 3 7} \\
(7.67) \\
\end{array}$ & $\begin{array}{l}\mathbf{0 . 0 5 9} \\
(3.12)\end{array}$ & $\begin{array}{l}\mathbf{- 0 . 0 7 0} \\
(6.07)\end{array}$ & $\begin{array}{c}\mathbf{0 . 0 7 4} \\
(3.47)\end{array}$ \\
\hline average rating & & & $\begin{array}{l}-0.101 \\
(1.54)\end{array}$ & $\begin{array}{l}\mathbf{0 . 2 4 2} \\
(3.03)\end{array}$ & $\begin{array}{c}\mathbf{- 0 . 3 9 9} \\
(6.07)\end{array}$ & $\begin{array}{l}0.062 \\
(0.72) \\
\end{array}$ & $\begin{array}{r}-\mathbf{- 0 . 4 0 5} \\
(5.16)\end{array}$ & $\begin{array}{c}-0.013 \\
(0.30)\end{array}$ & $\begin{array}{c}\mathbf{- 0 . 3 0 1} \\
(4.51)\end{array}$ & $\begin{array}{l}\mathbf{- 0 . 1 2 5} \\
(1.34)\end{array}$ & $\begin{array}{l}\mathbf{- 0 . 4 2 5} \\
(4.84)\end{array}$ & $\begin{array}{l}0.063 \\
(0.73) \\
\end{array}$ & $\begin{array}{c}-0.134 \\
(1.50)\end{array}$ & $\begin{array}{c}-\mathbf{- 0 . 1 7 8} \\
(2.58)\end{array}$ & $\begin{array}{c}-0.136 \\
(1.17)\end{array}$ \\
\hline irate & & & & & & $\begin{array}{r}-0.025 \\
(0.19) \\
\end{array}$ & $\begin{array}{l}0.095 \\
(0.66)\end{array}$ & $\begin{array}{l}0.113 \\
(0.16) \\
\end{array}$ & $\begin{array}{l}0.122 \\
(1.12)\end{array}$ & $\begin{array}{l}-0.011 \\
(0.08)\end{array}$ & $\begin{array}{l}0.100 \\
(0.67)\end{array}$ & $\begin{array}{l}0.070 \\
(0.56) \\
\end{array}$ & $\begin{array}{l}0.118 \\
(0.78)\end{array}$ & $\begin{array}{l}-0.042 \\
(0.61)\end{array}$ & $\begin{array}{c}0.176 \\
(1.23)\end{array}$ \\
\hline swap diff (10y-2y) & & & & & & $\begin{array}{r}\mathbf{- 0 . 5 6 2} \\
(3.62) \\
\end{array}$ & $\begin{array}{l}\mathbf{0 . 9 4 9} \\
(5.52) \\
\end{array}$ & $\begin{array}{r}\mathbf{- 0 . 2 4 2} \\
(2.87) \\
\end{array}$ & $\begin{array}{l}\mathbf{0 . 9 1 8} \\
(7.07)\end{array}$ & $\begin{array}{l}-\mathbf{- 0 . 4 8 2} \\
(3.03) \\
\end{array}$ & $\begin{array}{l}\mathbf{0 . 9 4 2} \\
(5.36) \\
\end{array}$ & $\begin{array}{r}-1.013 \\
(6.36) \\
\end{array}$ & $\begin{array}{l}\mathbf{0 . 9 3 3} \\
(5.37) \\
\end{array}$ & $\begin{array}{l}-\mathbf{- 0 . 6 1 6} \\
(6.50) \\
\end{array}$ & $\begin{array}{l}\mathbf{1 . 2 9 2} \\
(5.21)\end{array}$ \\
\hline curve (life*swap diff) & & & & & & \begin{tabular}{|l}
0.030 \\
$(1.20)$ \\
\end{tabular} & $\begin{array}{r}\mathbf{- 0 . 1 7 2} \\
(6.09) \\
\end{array}$ & $\begin{array}{l}0.005 \\
(0.40) \\
\end{array}$ & $\begin{array}{c}\mathbf{- 0 . 1 5 2} \\
(7.38) \\
\end{array}$ & $\begin{array}{l}0.012 \\
(0.44) \\
\end{array}$ & $\begin{array}{c}\mathbf{- 0 . 1 8 4} \\
(6.23) \\
\end{array}$ & $\begin{array}{l}\mathbf{0 . 1 3 8} \\
(5.30) \\
\end{array}$ & $\begin{array}{r}\mathbf{- 0 . 1 9 3} \\
(6.58) \\
\end{array}$ & \begin{tabular}{|l}
$\mathbf{0 . 0 8 0}$ \\
$(4.94)$ \\
\end{tabular} & $\begin{array}{r}\mathbf{- 0 . 2 2 7} \\
(5.94) \\
\end{array}$ \\
\hline auto & & & & & & & & $\begin{array}{l}\mathbf{0 . 9 4 9} \\
(3.55)\end{array}$ & $\begin{array}{l}0.375 \\
(0.91)\end{array}$ & $\begin{array}{l}\mathbf{3 . 0 3 7} \\
(4.62)\end{array}$ & $\begin{array}{l}-0.307 \\
(0.57)\end{array}$ & & & $\begin{array}{l}.278 \\
(6.51)\end{array}$ & $\begin{array}{l}0.046 \\
(0.10)\end{array}$ \\
\hline cards & & & & & & & & $\begin{array}{l}1.115 \\
(3.98) \\
\end{array}$ & $\begin{array}{l}0.167 \\
(0.39) \\
\end{array}$ & $\begin{array}{l}\mathbf{3 . 3 6 7} \\
(4.91) \\
\end{array}$ & $\begin{array}{l}-1.343 \\
(1.81) \\
\end{array}$ & & & $\begin{array}{l}1.491 \\
(7.04) \\
\end{array}$ & $\begin{array}{c}0.208 \\
(0.47) \\
\end{array}$ \\
\hline cdo & & & & & & & & $\begin{array}{c}\mathbf{2 . 6 9 2} \\
(10.86)\end{array}$ & $\begin{array}{l}\mathbf{1 . 6 3 2} \\
(4.27)\end{array}$ & $\begin{array}{l}\mathbf{6 . 2 5 1} \\
(9.58)\end{array}$ & $\begin{array}{l}\mathbf{1 . 8 1 3} \\
(3.81)\end{array}$ & & & $\begin{array}{c}\mathbf{2 . 2 8 3} \\
(11.72) \\
\end{array}$ & $\begin{array}{l}\mathbf{2 . 0 4 0} \\
(3.99)\end{array}$ \\
\hline cmbs & & & & & & & & $\begin{array}{c}\mathbf{2 . 6 4 5} \\
(10.24) \\
\end{array}$ & $\begin{array}{l}\mathbf{1 . 0 2 8} \\
(2.58)\end{array}$ & $\begin{array}{c}\mathbf{6 . 2 5 6} \\
(9.31) \\
\end{array}$ & $\begin{array}{l}\mathbf{1 . 0 5 6} \\
(2.14)\end{array}$ & & & $\begin{array}{c}\mathbf{2 . 4 7 3} \\
(10.73)\end{array}$ & $\begin{array}{c}\mathbf{1 . 3 5 9} \\
(2.95)\end{array}$ \\
\hline consumer & & & & & & & & $\begin{array}{l}\mathbf{1 . 6 7 8} \\
(6.02)\end{array}$ & $\begin{array}{l}0.271 \\
(0.63)\end{array}$ & $\begin{array}{l}\mathbf{4 . 4 5 5} \\
(6.57)\end{array}$ & $\begin{array}{l}-0.773 \\
(1.24)\end{array}$ & & & $\begin{array}{l}\mathbf{1 . 9 7 8} \\
(9.04)\end{array}$ & $\begin{array}{l}1.200 \\
(2.45)\end{array}$ \\
\hline equipment & & & & & & & & $\begin{array}{l}\mathbf{0 . 9 6 0} \\
(3.05)\end{array}$ & $\begin{array}{l}0.418 \\
(0.86)\end{array}$ & $\begin{array}{l}\mathbf{2 . 9 6 8} \\
(4.08)\end{array}$ & $\begin{array}{l}-0.474 \\
(0.66)\end{array}$ & & & $\begin{array}{l}1.271 \\
(4.73) \\
\end{array}$ & $\begin{array}{l}0.107 \\
(0.22)\end{array}$ \\
\hline other & & & & & & & & $\begin{array}{c}\mathbf{1 . 0 7 8} \\
(4.20)\end{array}$ & $\begin{array}{l}0.639 \\
(1.61)\end{array}$ & $\begin{array}{l}\mathbf{2 . 9 8 8} \\
(4.59)\end{array}$ & $\begin{array}{l}0.164 \\
(1.70)\end{array}$ & & & $\begin{array}{r}\mathbf{1 . 0 7 9} \\
(5.17) \\
\end{array}$ & $\begin{array}{c}0.637 \\
(1.40)\end{array}$ \\
\hline rmbs & & & & & & & & $\begin{array}{l}\mathbf{1 . 6 4 0} \\
(6.97)\end{array}$ & $\begin{array}{c}\mathbf{0 . 8 7 4} \\
(2.41)\end{array}$ & $\begin{array}{l}\mathbf{4 . 3 2 8} \\
(6.96)\end{array}$ & $\begin{array}{c}0.744 \\
(1.70)\end{array}$ & & & $\begin{array}{c}\mathbf{1 . 6 6 0} \\
(10.39)\end{array}$ & $\begin{array}{c}0.853 \\
(1.97)\end{array}$ \\
\hline whole business & & & & & & & & $\begin{array}{r}\mathbf{1 . 4 2 6} \\
(4.93)\end{array}$ & $\begin{array}{l}1.122 \\
(2.52)\end{array}$ & $\begin{array}{l}\mathbf{3 . 8 6 1} \\
(5.45)\end{array}$ & $\begin{array}{l}1.239 \\
(2.24)\end{array}$ & & & $\begin{array}{l}\mathbf{0 . 5 9 1} \\
(2.46)\end{array}$ & $\begin{array}{c}\mathbf{1 . 9 5 8} \\
(3.12)\end{array}$ \\
\hline pseudo-R ${ }^{2}$, adj. $\mathrm{R}^{2}$ (OLS) & 0.08 & 0.10 & 0.10 & 0.09 & 0.10 & 0.10 & 0.11 & 0.33 & 0.31 & 0.15 & 0.13 & 0.04 & 0.11 & 0.25 & 0.31 \\
\hline no. of observations & 1605 & 1605 & 968 & 968 & 968 & 838 & 838 & 838 & 838 & 838 & 838 & 838 & 838 & 838 & 838 \\
\hline
\end{tabular}


In order to test these hypotheses we proxy the quality of assets in each issue by the weighted average composite rating index of an issue, where 6 is assigned to AAA tranches and 0 to the non-rated tranches. However, when we add this proxy for quality to our model, it turns out to be insignificant. Finally, Plantin (2004) predicts that less information-sensitive assets should be tranched when there are more sophisticated investors in the market and market sophistication overall is higher. This would imply interaction between the time dimension as measured by time index as a proxy for market sophistication and the type-ranking of assets. To test this prediction we interact year with type (not reported), but the coefficient is not significant.

4.3 RATING ClasSES AND SAME-RATED MARKET ClasSES: One potential problem with information asymmetry models is that any ex ante information asymmetries might be eliminated by the rating process. However, since at least some junior tranches are often unrated, the credit rating agencies might actually exaggerate the information asymmetry between junior and senior tranches. Complexity of securitisations means technology might often add to these differences. ${ }^{21}$ Moreover, asymmetric information theories face difficulties explaining tranching within a given rating class, since it is not clear how such 'extra' tranches differentiate between sophisticated and unsophisticated investors. An alternative set of possible justifications for tranching is based on market incompleteness. As DeMarzo and Duffie (1999) point out: "The motivation for 'splitting' securities in this setting [with asymmetric information] is independent of motivations due to spanning or clientele effects". ${ }^{22}$ Under market incompleteness tranching becomes a process by which new securities, not available before, are created.

To investigate these issues better, we next split tranches into two groups. First, for each issue we calculate the number of unique rating groups according to the 'Moody's extended rating', which is more precise than the composite rating because it includes all refinements. ${ }^{23}$ The result is the number of 'rating classes' uniquely defined by credit ratings. For example, an issue of 5 tranches with 2 AAA-rated tranches, 2 BB-rated tranches, and a single B-rated tranche will feature 3 rating classes. Non-rated issues are not considered to be a separate rating class.

The number of rating classes would be equal to the number of tranches if all tranches were differentiated by rating. However, some additional tranches (after the rating differentiation) are often created within the same 'rating class' by differentiating the securities issued in terms of the currency, the weighted average life, the payment structure, or other. It is commonly reported in the professional literature that they are created to meet "investors' needs". To capture those, we calculate the number of such extra 'market classes' equal to the difference between the overall number of tranches and the number of rating classes for each issue. There exist, on average, 1.14 additional same-rated 'market classes' per issue vis-à-vis 2.07 rating classes. The maximum number of rating classes is 6 , but there are some issues that have as many as 13 additional same-rated market classes. $56 \%$ of all issues have 2, 3 or 4 rating classes (14\% of issues have no 'rating' classes), but over $44 \%$ of all issues have no additional, same-rated 'market classes'.

Since the same-rated market classes are not differentiated by rating, but only by market characteristics, they are predicted to be related to clientele effects and designed to exploit market incompleteness or as a remedy for market segmentation controlling for the liquidity problem. It is more difficult to explain the existence of those market classes from the asymmetric information security design vantage point. ${ }^{24}$ On the other hand, it is clear that the rating classes

\footnotetext{
${ }^{21}$ For example, proprietary MBS and ABS valuation models, used by intermediaries and some sophisticated investors but not available to others, contribute to the asymmetry.

${ }^{22}$ DeMarzo and Duffie (1999), p. 95.

${ }^{23}$ We use the Moody's extended rating index in order to capture all possible distinctions between different tranches in terms of ratings.

${ }^{24}$ Naturally, this distinction is not perfect. Occasionally, an 'extra class' is differentiated from one of the rating classes by seniority, despite having the same rating, but a different level of enhancement. In those cases, the creation of an 'extra class' can still be, at least theoretically, explained by the 'asymmetric information' arguments. At the same time, creating different rating classes might be explained by market segmentation or incompleteness.
} 
should be primarily associated with the asymmetric information theories of tranching if the latter are correct. This division is not without precedent in theoretical literature. Riddiough (1997), for example, suggests that although two classes might be created to differentiate informed and uninformed investors, further tranching might be necessary to place an issue due to 'clientele effects'.

The division between rating classes and same-rated market classes allows us to compare and contrast the potential effects of asymmetric information versus market segmentation, incompleteness and liquidity effects. To do this, we conduct the same tests as before for 'rating classes' and the same-rated 'market classes' separately. The results are reported in regressions IV and V in Table 11. It is clear that different effects influence these two sub-groups of tranches very differently: The coefficient on the information asymmetry index is over $70 \%$ greater than and almost twice as significant for the number of rating classes as for the number of same-rated extra market classes. However, this pattern is reversed for the size factor - our proxy for liquidity and segmentation effects - where the coefficient on size is now over twice as high for the rating classes as for the same-rated market classes and almost twice as significant. This is as predicted by theory since the issue size is not predicted to be an important determinant of tranching by the asymmetric information literature.

Equally significant is the implication of this distinction between two classes for the significance of our proxy for the quality of assets - the weighted average rating - which is now strongly significant in both cases, but in opposite direction. This seems to confirm that higher quality assets are tranched more as far as tranching is associated with remedying the problem of asymmetric information, as predicted by the asymmetric information literature. At the same time, some additional tranches (the same-rated market classes) are typically created in the case of poor quality assets, when the latter might be more difficult to place. Moreover, the year index as a proxy for investors' sophistication is now significant for the rating classes only and hence can be entirely associated with asymmetric information; it does not have a significant impact on the number of the same-rated market classes per issue. Finally, longer expected life is associated with a larger number of the same-rated market classes, perhaps because it facilitates the creation of the same-rated market classes only distinguished by expected life. However, a long expected life of an issue might pose problems for seniority-tranching by making it difficult to create a AAA-rated tranche necessary to appeal to unsophisticated investors. This is supported by the fact that although AAA-rated tranches represent $77 \%$ of all tranches with expected maturity of less than 2 years, they represent only 26\% of tranches with life longer than 7 years.

We also investigate the impact of market conditions by including controls for the three leading bond market characteristics: the level of interest rate (proxied by the corresponding 10year government bond), the slope of the yield curve (proxied by the 10-year minus 2-year swap differential) and the 'curve' - the interaction variable of weighted average expected life per issue and the slope of the yield curve since the yield curve might be expected to have a different impact on issues of different maturities. We expect the number of the same-rated market classes to be higher in severe bond market conditions when more effort might be needed to cater for investors' specific tastes or for exploring market niches, especially when placing the junior tranches of each issue. Our results (equations VI and VII) broadly confirm this view. Although the interest rate is not significant, a steep yield curve, associated with rising interest rates in the future (and hence falling bond prices), is related to a greater number of the same-rated market classes being carved out, as expected, but a lower number of rating classes. Also, the coefficient on the interaction variable of life and the slope, another proxy for market conditions, is negative and very significant for the same-rated market classes

In order to explore the distinction between the rating classes and the same-rated market classes further, we test the impact of additional factors, which might have a different effect on the two groups of tranches. For example, we would expect the asset type characteristics to have a dominant impact upon the number of rating classes per issue and the market conditions to primarily influence the number of the same-rated market classes per issue. To test the former, we 
now replace the info-asymmetry index with individual dummies for all asset types (regressions VIII-IX using OLS, X-XI with ordered logit). ${ }^{25}$ The impact of asset dummies turns out to be much stronger on the number of rating classes than on the number of the same-rated market classes, as expected. Whereas a dummy on each asset type is significant at the $1 \%$ level for the number of rating classes, only the CDO dummy (out of 10 different asset types) has a strong and significant impact on the number of same-rated market classes. This result underlines the difference in the impact of the information-asymmetry asset type index on the rating classes and the same-rated market classes as reported earlier. It also provides an important robustness check by showing that our results are not dependent on any single group of assets such as the CDOs.

4.4 RATING SIBLINGS AND UNIQUELY RATED TRANCHES: Our measure of the number of additional, 'market' classes might not fully capture the extent of variation between tranches of the same rating. In order to better understand drivers behind the creation of such tranches and to test robustness of our previous findings, we now divide the total number of tranches according to an alternative classification of: (i) rating 'siblings' - i.e. tranches such that there exist other tranches in a given issue with the same rating, and (ii) uniquely rated tranches per issue. ${ }^{26}$

We conduct the same tests as for the rating/market classes, which confirm and occasionally strengthen our previous results (regressions XII-XV). For example, asset type dummies are even more significant for the number of uniquely rated tranches than in the case of rating groups, whereas they are equally insignificant for the number of 'siblings' and additional market classes. Moreover, the size factor is now not only stronger and more significant for the number of 'siblings', but it is no longer significant in the case of uniquely rated tranches. Other factors, such as WAL and the 'curve', are now not only of opposite sign, but also highly significant for both sub-groups of tranches.

\section{Tranching and Pricing}

5.1 The PRICING MODEL: We now turn to test whether a higher predicted number of tranches is associated with a systematically different launch spread - the price at which the previously structured securities are sold to the market. ${ }^{27}$ To do this we adopt a simple pricing model set in this context by Cuchra (2004). Our set of controls is similar to those typically used in the 'reduced form' models from the existing literature on bond pricing. ${ }^{28}$ We use standard market controls including the interest rate level (proxied by the government 10-year benchmark bond), the slope of the yield curve (proxied by the difference between the 10-year and the 2-year government bond), as well as the implied volatility of interest rates and the tranche's expected life, both of which are important due to embedded options. ${ }^{29}$ We also include additional controls: the index of the enhancement level (class rank), which is aimed at capturing differences in seniority and cashflow rights between different classes of the same issue over and beyond the credit rating; and the total number of lead managers (arrangers), since it might be related to the

\footnotetext{
${ }^{25}$ We report OLS results with robust standard errors for comparison. This might be important since differences in the number of ratings might carry more information than a simple ordinal ranking.

${ }^{26}$ The average number of siblings per issue is almost identical to the average number of additional same-rated, market tranches per issue (1.143 vs. 1.142), but the standard deviation is significantly greater (2.238 vs. 1.675). The two classifications differ in potentially important ways. Note that non-rated tranches are classified as 'uniquely rated' rather than as 'siblings' consistent with the assumption that they are do not represent a separate rating class and therefore can be thought of as 'unique'. For example, consider an issue with 4 tranches: 2xAAA, 2xA-. The number of additional, same-rated market tranches is 2 for this issue, but the number of siblings is 4 . The differences between the number of uniquely rated tranches per issue and the number of rating groups per issue, as introduced earlier, represent the mirror image of the differences described above.

${ }^{27}$ Note that we are not testing here whether tranching is efficient or whether it adds value directly.

${ }^{28}$ See e.g. Campbell and Taskler (2003).

${ }^{29}$ Note that the number of tranches per issue is predicted in the $1^{\text {st }}$ stage regression using the issue characteristics and date-specific market controls, where the latter are taken from the market of the currency of the most senior tranche, whereas the market controls in the pricing regression are specific to the currency of that particular tranche.
} 
placement effort. Our regressions also include dummies for all asset types, each composite rating category, year and the month of issue. Since tranches of the same issue are clearly related, all our Hubber-White standard errors incorporate adjustments for clustering by issue.

Our pricing sample is smaller than the entire set because we eliminate all issues where at least one tranche of an issue has at least one control missing: we eliminate all issues where we lack the launch spread, cannot identify the currency of issue, for which no relevant benchmark can be found, or the key control variables are not available for at least one tranche. We also eliminate issues denominated in currencies other than euro, US dollar, or pound sterling and exclude all issues with a non-European country of origin of assets, as well as issues classified just as 'European' or 'international'. ${ }^{30}$ We also remove all issues that contain fixed rate tranches because they might require a different pricing model.

5.2 RELATIONSHIP BETWEEN TRANCHING AND PRICING: The results are presented in Table 12. We start by noting that the issue size has a significant and negative impact on launch spread (regression I) - i.e. a positive impact on the net price paid by investors to the issuer. Since size is a major determinant of the number of tranches, we expect some of this effect to be accounted for by tranching. However, the issue size might also be important independently of tranching. First, if there is limited market segmentation then the issue size might be a proxy for liquidity; second, it might act as a proxy for originator's reputation, size and name recognition, which would be independent of any structuring. However, we would expect the latter effect to be less important for securitisation issues than for corporate bonds since pools of securitised assets are likely to be less idiosyncratic across originators than the originating firms themselves. Also, a positive coefficient on size would indicate that placing a large issue poses problems despite tranching. For comparative purposes, we include a test of the actual number of tranches (regression II) and note that although the coefficient on tranches is insignificant, issue size remains very significant and of roughly the same magnitude. We also note that other coefficients have the correct sign and reasonable magnitudes, although coefficients on the interest rate level and each tranche's expected life are never significant.

We now predict the simple total number of tranches using our model outlined in section 4 (regressions III and IV) including all individual asset types (to proxy for the asymmetry of information and any other potential, type-specific characteristics), as well as the year index (to capture differences in investors' sophistication and market development), and the issue size (to capture tranching due to market segmentation, incompleteness and liquidity effects). Our model also includes the issue's expected weighted average life and the quality of assets per issue (proxied by the weighted average rating per issue) as well as a set market factors: the interest rate, a proxy for the slope of the yield curve, and the implied volatility of interest rates, which might be related to segmentation and incompleteness, as explained in the previous section. For comparative purposes, we use the ordered logit as well as the least squares methods.

Although the coefficient on the predicted total number of tranches is not significant in either case, it is consistently negative and considerably stronger as well as being more significant for ordered logit predictions (other differences between the two models are small). ${ }^{31}$ Note that, if significant, it would imply a positive relationship between the number of tranches and price. Under our assumption of the optimal number of tranches chosen to maximize the value of assets, a positive correspondence between the predicted number of tranches and price would indicate that for issues with a higher optimal number of tranches arrangers are able to achieve a better price, controlling for other factors. That is, in circumstances predicted by our model to be

\footnotetext{
${ }^{30}$ These issues constitute less than $10 \%$ of all issues and they are typically priced against benchmarks other than LIBOR or EURIBOR.

${ }^{31}$ When using the OLS, we predict the log of the number of tranches (to avoid the problem of normal distribution and truncation of the sample at zero) and then convert our predicted logs into the actual number of tranches. We do not use the OLS for separate rating groups/additional same-rated market classes predictions as they contain 226/709 ‘zero’ outcome observations, respectively.
} 
associated with more tranching (at the optimum), the price effect of those circumstances via tranching is positive. This would imply that, given arranger's access to structuring technology and hence the ability to tranche, greater market sophistication, asymmetric information, market incompleteness, and all other factors, which our model associates with more tranching, would have a net, overall positive effect on price.

\section{TABLE 12: TRANCHING AND PRICING}

Dependent variable is the launch yield spread (in bps) above LIBOR for floating rate issues. All tranches are floating rate. Each observation represents a single tranche. Independent variables: tranches is the predicted number of tranches from the $1^{\text {st }}$ stage regression as specified (actual in regression II); 'issuesize' is the issue size (of which a given tranche is a part of) in US\$ converted from the issue currency at the FX rate at the date of issue; 'irate' is the yield on a 10-year government benchmark in the currency of issue on the day of issue; 'swapdiff' (slope) is the difference between a 10-year and a 2-year swap yield in the currency of issue on the day of issue; 'capvol' is the implied volatility of a 5-year interest rate cap in the currency of issue on the day of issue; 'life' is the expected weighted average life of a security in years as per assumed prepayment path (where relevant); asset types are auto-loans, credit card loans, cdo, cmbs, (other) consumer loans, equipment leases, other, rmbs, whole business, and government/agency securitisations (omitted); 'leadtot' is the total number of lead and co-lead managers (arrangers) for each transaction. AAA to BB are dummies for the respective composite credit rating category of each tranche (t-statistics omitted). Bold font indicates significance at the $1 \%$ level. Bold italic indicates significance at the $5 \%$ level, significance at $10 \%$ level not reported. All regressions include a constant (not reported). All regressions include year and month dummies (coefficients not reported). All fixed-rated tranches are omitted; all tranches in issues for which at least one pricing factor/control is not specified for at least one tranche are omitted. T-statistics calculated from the Huber-White robust errors with specified clustering of tranches within each issue are reported in brackets.

\begin{tabular}{|c|c|c|c|c|c|c|c|c|}
\hline regression & I & II & III & IV & V & VI & VII & VIII \\
\hline $1^{\text {st }}$ stage model & - & actual & ols & ologit & ologit & ologit & ologit & ologit \\
\hline predicted variable & - & $\begin{array}{l}\text { all tranches } \\
\text { (all) }\end{array}$ & $\begin{array}{l}\text { all tranches } \\
\text { (jointly) }\end{array}$ & $\begin{array}{l}\text { all tranches } \\
\text { (jointly) }\end{array}$ & $\begin{array}{c}\text { all tranches } \\
(\mathrm{RC}+\mathrm{MC})\end{array}$ & $\begin{array}{c}\text { (RC) rating } \\
\text { classes }\end{array}$ & $\begin{array}{c}\text { (MC) mkt } \\
\text { classes }\end{array}$ & $\begin{array}{c}\text { all tranches } \\
(\mathrm{RC}+\mathrm{MC})\end{array}$ \\
\hline all tranches & - & $\begin{array}{l}-0.026 \\
(-0.03)\end{array}$ & $\begin{array}{l}-0.822 \\
(-0.17)\end{array}$ & $\begin{array}{l}-3.228 \\
(-0.92)\end{array}$ & $\begin{array}{l}-3.256 \\
(-0.75)\end{array}$ & - & - & - \\
\hline $\begin{array}{l}\text { rating classes } \\
\text { (uniquely-rated) }\end{array}$ & - & - & - & - & - & $\begin{array}{l}-13.768 \\
(-2.33) \\
\end{array}$ & - & $\begin{array}{l}-14.674 \\
(-2.26) \\
\end{array}$ \\
\hline $\begin{array}{l}\text { market classes } \\
\text { (same-rated) }\end{array}$ & - & - & - & - & - & - & $\begin{array}{l}-1.205 \\
(-0.19) \\
\end{array}$ & $\begin{array}{l}-1.514 \\
(-0.23) \\
\end{array}$ \\
\hline issuesize & $\begin{array}{l}\mathbf{- 0 . 0 0 9} \\
(-5.63) \\
\end{array}$ & $\begin{array}{l}\mathbf{- 0 . 0 0 9} \\
(-4.22) \\
\end{array}$ & $\begin{array}{l}-\mathbf{- 0 . 0 0 7} \\
(-2.76) \\
\end{array}$ & $\begin{array}{l}-0.005 \\
(-2.18) \\
\end{array}$ & $\begin{array}{l}-0.005 \\
(-1.61) \\
\end{array}$ & $\begin{array}{l}-0.005 \\
(-2.46) \\
\end{array}$ & $\begin{array}{l}-0.007 \\
(-1.99) \\
\end{array}$ & $\begin{array}{l}-0.006 \\
(-1.85) \\
\end{array}$ \\
\hline irate $_{10 y}$ & $\begin{array}{l}-5.209 \\
(-1.20)\end{array}$ & $\begin{array}{l}-5.199 \\
(-1.20)\end{array}$ & $\begin{array}{l}-0.575 \\
(-0.14) \\
\end{array}$ & $\begin{array}{l}-0.547 \\
(-0.14)\end{array}$ & $\begin{array}{l}-0.619 \\
(-0.15)\end{array}$ & $\begin{array}{l}-1.463 \\
(-0.37)\end{array}$ & $\begin{array}{l}-0.502 \\
(-0.12)\end{array}$ & $\begin{array}{l}-1.594 \\
(-0.40)\end{array}$ \\
\hline swapdiff (slope) & $\begin{array}{l}-14.067 \\
(-4.67) \\
\end{array}$ & $\begin{array}{l}-14.064 \\
(-4.67) \\
\end{array}$ & $\begin{array}{c}-14.924 \\
(-4.84) \\
\end{array}$ & $\begin{array}{r}-\mathbf{1 5 . 3 9 9} \\
(-5.10) \\
\end{array}$ & $\begin{array}{c}-\mathbf{- 1 5 . 2 8 0} \\
(-5.05) \\
\end{array}$ & $\begin{array}{l}\mathbf{- 1 5 . 7 9 7} \\
(-5.30) \\
\end{array}$ & $\begin{array}{c}-14.871 \\
(-4.90)\end{array}$ & $\begin{array}{c}-15.741 \\
(-5.25)\end{array}$ \\
\hline capvol $_{5 y \mathrm{i} / \text { r cap }}$ & $\begin{array}{l}1.764 \\
(4.17)\end{array}$ & $\begin{array}{l}1.766 \\
(4.18)\end{array}$ & $\begin{array}{l}\mathbf{1 . 5 6 1} \\
(3.89)\end{array}$ & $\begin{array}{l}\mathbf{1 . 5 5 9} \\
(3.72)\end{array}$ & $\begin{array}{l}\mathbf{1 . 5 8 3} \\
(3.67)\end{array}$ & $\begin{array}{l}\mathbf{1 . 2 5 1} \\
(3.03)\end{array}$ & $\begin{array}{l}\mathbf{1 . 6 0 6} \\
(3.14)\end{array}$ & $\begin{array}{l}1.190 \\
(2.19)\end{array}$ \\
\hline life $_{\exp }$ (WAL) & $\begin{array}{l}-0.473 \\
(-0.87) \\
\end{array}$ & $\begin{array}{l}-0.474 \\
(-0.86) \\
\end{array}$ & $\begin{array}{l}-0.419 \\
(-0.79) \\
\end{array}$ & $\begin{array}{l}-0.530 \\
(-1.01) \\
\end{array}$ & $\begin{array}{l}-0.504 \\
(-0.95) \\
\end{array}$ & $\begin{array}{l}-0.719 \\
(-1.37) \\
\end{array}$ & $\begin{array}{l}-0.402 \\
(-0.75) \\
\end{array}$ & $\begin{array}{l}-0.723 \\
(-1.37) \\
\end{array}$ \\
\hline classrank & $\begin{array}{l}4.817 \\
(4.77)\end{array}$ & $\begin{array}{l}\mathbf{4 . 8 3 5} \\
(5.14)\end{array}$ & $\begin{array}{l}\mathbf{4 . 0 3 7} \\
(3.65)\end{array}$ & $\begin{array}{l}\mathbf{4 . 0 6 7} \\
(3.63)\end{array}$ & $\begin{array}{l}\mathbf{4 . 0 6 1} \\
(3.62)\end{array}$ & $\begin{array}{l}\mathbf{3 . 9 5 1} \\
(3.52)\end{array}$ & $\begin{array}{l}\mathbf{4 . 0 6 0} \\
(3.60)\end{array}$ & $\begin{array}{l}\mathbf{3 . 9 2 7} \\
(3.42)\end{array}$ \\
\hline leadtot & $\begin{array}{l}-4.291 \\
(-2.90) \\
\end{array}$ & $\begin{array}{l}-\mathbf{- 4 . 2 8 8} \\
(-2.92) \\
\end{array}$ & $\begin{array}{l}-3.106 \\
(-2.03) \\
\end{array}$ & $\begin{array}{l}-3.071 \\
(-1.96) \\
\end{array}$ & $\begin{array}{l}-3.122 \\
(-2.01) \\
\end{array}$ & $\begin{array}{l}-2.832 \\
(-1.83) \\
\end{array}$ & $\begin{array}{l}-3.131 \\
(-2.07) \\
\end{array}$ & $\begin{array}{l}-2.774 \\
(-1.86) \\
\end{array}$ \\
\hline $\mathrm{AAA}_{\text {rating }}(\mathrm{d})$ & -140.45 & -140.40 & -155.99 & -156.79 & -157.47 & -155.94 & -156.33 & -155.15 \\
\hline $\mathrm{AA}_{\text {rating }}(\mathrm{d})$ & -120.32 & -120.29 & -134.88 & -135.81 & -136.48 & -135.12 & -135.20 & -134.32 \\
\hline $\mathrm{A}_{\text {rating }}$ (d) & -87.55 & -87.53 & -106.24 & -106.81 & $\begin{array}{l}-107.53 \\
\end{array}$ & -105.99 & -106.58 & -105.28 \\
\hline $\mathrm{BBB}_{\text {rating }}(\mathrm{d})$ & 11.53 & 11.55 & -10.39 & -11.09 & -11.81 & -10.04 & -10.77 & -9.25 \\
\hline $\mathrm{BB}_{\text {rating }}(\mathrm{d})$ & 242.22 & 242.22 & 200.30 & 200.09 & 199.17 & 201.65 & 199.81 & 202.43 \\
\hline $\begin{array}{l}9 \text { asset type } \\
\text { dummies }\end{array}$ & Yes & Yes & Yes & Yes & Yes & Yes & Yes & Yes \\
\hline $\begin{array}{l}8 \text { year } \\
\text { dummies }\end{array}$ & Yes & Yes & Yes & Yes & Yes & Yes & Yes & Yes \\
\hline $\begin{array}{l}11 \text { month } \\
\text { dummies }\end{array}$ & Yes & Yes & Yes & Yes & Yes & Yes & Yes & Yes \\
\hline $\begin{array}{l}\text { clusters } \\
\text { (issues) }\end{array}$ & 953 & 953 & 802 & 802 & 802 & 802 & 802 & 802 \\
\hline fixed / floating & float only & float only & float only & float only & float only & float only & float only & float only \\
\hline $\mathrm{R}^{2}$ & 76.2 & 76.2 & 76.3 & 76.3 & 76.3 & 76.4 & 76.3 & 76.4 \\
\hline $\begin{array}{l}\text { \# of observations } \\
\text { (tranches) }\end{array}$ & 2985 & 2985 & 2519 & 2519 & 2519 & 2519 & 2519 & 2519 \\
\hline
\end{tabular}


However, a negative relationship between the number of predicted tranches and price would not necessarily imply that tranching is inefficient or that it does not add value. Instead, it would seem to indicate that in issues with a higher optimal number of tranches arrangers are still achieving lower prices despite tranching. ${ }^{32}$ This would imply that factors such as asymmetric information or market segmentation, which we have associated in our model with a higher optimal level of tranching, would have a net negative effect on price. In this case, tranching could be preventing investors from discounting those issues even further, but we do not find evidence to support this interpretation.

Our results also indicate that the impact of issue size remains of consistently similar magnitude. This seems to confirm the hypothesis that: (i) either the market is less segmented than expected, or (ii) tranching is successful in remedying the problem of market segmentation in as far as the latter calls for more tranching. In other words, it indicates that tranching seems to be removing any potential downward sloping demand curve effect, which would imply a price discount on larger issues. This conclusion is consistent with the positive relationship between the predicted number of tranches and price, if tranching is indeed able to remedy the segmentation problem while extracting additional benefits under the circumstances where a higher number of tranches is optimal.

To better understand these issues, we now independently predict the number of uniquelyrated classes and the number of same-rated market classes per issue using the ordered logit model (regression $\mathrm{V}$ ) and then add them up to get the composite total predicted number of tranches. We suspect that the predicted composite total number of tranches might be more precise than the total number of tranches where both groups are jointly predicted. However, the coefficient on the number of tranches is still insignificant while being of the same magnitude and direction as before. It is worth noting that the coefficient on size is no longer significant, but remains of the same magnitude and direction.

In order to capture potentially different relationships between prices of securities issued and market circumstances in situations where (i) a higher number of rating classes is optimal, and (ii) a higher number of same-rated market classes is optimal, separately, we now enter these measures of tranches independently, one-by-one, into our pricing model (regression VI and VII), as specified before. The coefficient on the rating classes is now large, negative and significant (regression VI). This positive correspondence between the predicted number of rating groups and price indicates that for issues with a higher optimal number of rating groups arrangers are able to achieve better prices. In other words, in circumstances predicted by our model to be associated with more rating groups being created - i.e. where there is greater investors' sophistication, more information asymmetry and greater diversification across investors - the effect of those circumstances on price via tranching is positive (given arranger's access and optimal use of structuring technology). It follows that tranching seems to be allowing issuers to exploit market factors such as asymmetric information to their advantage via arranger's structuring policy (in response to market and assets' characteristics of a particular issue).

In contrast, the coefficient on the same-rated market classes remains insignificant despite being consistently negative (regression VII). This is confirmed when we enter both groups of tranches together in regression VIII: the coefficient on the rating classes remains large and significant, but the coefficient on the same-rated market classes remains insignificant. This further supports the hypothesis that tranching might be successful in remedying the problem of market segmentation (where present) so that large issues associated with a higher number of market classes, when tranched, do not carry a negative impact on price. If the coefficient on the same-rated market classes were positive, tranching could still be adding value by diminishing

\footnotetext{
${ }^{32}$ That is, in circumstances predicted by our model to be associated with more tranching, the price effect of those circumstances affecting the price via tranching would be negative.
} 
any potential 'segmentation discount' on price, but the net effect would remain negative. ${ }^{33}$ Instead, the observed relationship is positive (the coefficient is negative), but not significant.

It should also be noted that although the net effect on price seems to be zero or positive in this case, it could be due to factors other than the presumed successful response to the market segmentation problem. For example, in so far as our first-stage model is capturing tranching with the same-rated classes due to market incompleteness, the positive impact on price from additional, same-rated tranches aimed to exploit market niches might be neutralizing the negative effect of market segmentation, which tranching is unable to remedy completely.

\section{CONCLUSIONS}

Securitizations have become established as an important source of finance for financial institutions and companies. Tranching is the process by which securitisation issues are structured, by creating different securities with different risk, duration or other characteristics backed by the same pool of assets. Although such structured financings have become an increasingly important function within investment banks, there has been little academic research on the subject beyond pure theory. This paper represents the first attempt to shed empirical light on the key factors that determine the tranching decision.

We have tested several key hypotheses regarding tranching derived from the security design literature. We find strong support for the theoretical prediction that greater sophistication of investors and progressive market development should be associated with more tranching. On this basis, we estimate that European securitisation markets seem to be several years behind the US. Next, we show that a greater degree of asymmetric information is associated with a higher optimal number of tranches issued in any given deal. Again, this is in line with theoretical predictions. We also find some support for more nuanced modelling predictions such as the positive impact of the average quality of assets on tranching.

Most importantly, we show that different explanations of tranching are responsible for the creation of different groups of tranches in the same deal. Alongside tranching driven by information asymmetry we delineate tranching driven by market conditions such as market segmentation, incompleteness and post-issuance liquidity, and show the factors associated with each of those groups.

Finally, we investigate the effect of tranching on the pricing of issues at launch. We find evidence that tranching might be successful in remedying problems of market segmentation. For those issues where our model predicts a higher optimal number of tranches, we find that additional uniquely-rated tranches are associated with higher prices for the issue as a whole. This suggests that structuring is allowing issuers to exploit market factors - such as greater investor sophistication and heterogeneous screening skills related to asymmetric information - to their advantage via tranching.

\footnotetext{
${ }^{33}$ Assuming tranching is optimized to add value, a positive coefficient would indicate that although tranching might be remedying some effects of market segmentation, it cannot remedy it completely with a residual negative effect on price in the case of those issues where more market-classes are optimal. Again, we do not find evidence to supportr this interpretation.
} 


\section{REFERENCES:}

Allen, F. and D. Gale (1988): 'Optimal Security Design', Review of Financial Studies, 1 (3) (Autumn 1988), p. 229-263.

Allen, F. and D. Gale (1991): ‘Arbitrage, Short Sales, and Financial Innovation’, Econometrica, 59 (4), 1041-1068.

Allen, F. and D. Gale (1994): Financial Innovation and Risk Sharing, Cambridge, MA: MIT Press.

Ammer, J. and N. Clinton (2004): 'Good News is No News: The Impact of Credit Rating Changes on the Pricing of Asset-Backed Securities’, International Finance Discussion Papers \# 809, Federal Reserve Board, NY.

Black, F., and M. Scholes (1973): 'The pricing of options and corporate liabilities', Journal of Political Economy 81, 637-654.

Bolton, P. and Scharfstein, M. (1996). 'Optimal Debt Structure and the Number of Creditors'. Journal of Political Economy, 104:1-25.

Boudoukh, J., M. Richardson, R. Stanton and R. Whitelaw (1997): 'Pricing Mortgage-Backed Securities in a Multifactor Interest Rate Environment: A Multivariate Density Estimation Approach', Review of Financial Studies, Vol. 10, No. 2, New York.

Boot, A., and A. Thakor (1992): 'Security Design', Journal of Finance, 48, 1349-1378.

Campbell, J., G. Taskler (2003): 'Equity Volatility and Corporate Bond Yields', Journal of Finance, 2321-2349.

Campbell, J., A. Lo, A. MacKinlay, 1997, The Econometrics of Financial Markets. Princeton University Press, Princeton, NJ.

Chen, L., L. David and J. Zhanshun Wei, (2004): ‘Corporate Yield Spreads and Bond Liquidity’, working paper.

Collin-Dufresne, P. and R. Goldstein, (2001): 'Do credit spreads reflect stationary leverage ratios?', Journal of Finance 56, 1929-1957.

Collin-Dufresne, P. and R. Goldstein, and J. S. Martin, (2001): 'The determinants of credit spread changes', Journal of Finance 56, 2177-2207.

Cuchra, M. Firla-, (2002, rev. 2004): 'Financial contracting at the Boundary of a Firm', working paper, Department of Economics, Oxford University, UK.

Cuchra, M. Firla-, (2004): 'Explaining Launch Spreads in European Securitisations', working paper, Department of Economics, Oxford University.

Delianedis, G. and R. Geske, (2001): 'The Components of Corporate Credit Spreads: Default, Recovery, Tax, Jumps, Liquidity, and Market Factors', working paper, UCLA.

DeMarzo, P. (1997, rev 2001): 'The Pooling and Tranching of Securities: A Model of Informed Intermediation', working paper.

DeMarzo, P. (2005): 'The Pooling and Tranching of Securities: A Model of Informed Intermediation', Review of Financial Studies 18, 1-36.

Duffie, G. R., (1998): ‘The relation between treasury yields and corporate bond yield spreads', Journal of Finance 53, 2225-2241.

Duffie, D., and K. J. Singleton (1997): 'An econometric model of the term structure of interest-rate swap yields', Journal of Finance 52, 1287-1321.

Duffie, D., and K. J. Singleton (1997): 'Modelling term structures of defaultable bonds', Review of Financial Studies 12, 687-720.

Ederington, L. H., J. B. Yawitz, and B. E. Roberts, (1987): 'The informational content of bond ratings', Journal of Financial Research 10, 211-226.

Elton, E., M. Gruber, D. Agrawal, and C. Mann, (2000): 'Factors affecting the valuation of corporate bonds', unpublished paper, New York University.

Elton, E., (1999): 'Expected return, realized return, and asset pricing tests’, Journal of Finance 54, 11991221.

Elton, E., M. Gruber, D. Agrawal, and C. Mann, (2001): 'Explaining the rate spread on corporate bonds', Journal of Finance 56, 247-278.

Fabozzi, F. and L. Goodman (2001): 'Investing in Collateralized Debt Obligations’, Frank J. Fabozzi Associates.

Harris, M., and Raviv, A., (1988): 'The Design of Securities’, Journal of Financial Economics, 24:25587. 
Hu, J. and R. Cantor, (2003): 'Structured Finance Rating Transactions 1983-2002: Comparisons with Corporate Ratings and Across Sectors', Moody's Investors Service, New York.

Iacobucci, E., and R. Winter, (2005): 'Asset Securitization and Asymmetric Information', Journal of Legal Studies, 34:161-206.

Liu, J., F. Longstaff, and R. Mandell (2000): 'The market price of credit risk: An empirical analysis of interest rate swap spreads', unpublished paper, UCLA.

Longstaff, F., and E. Schwartz (1995): 'A simple approach to valuing risky fixed and floating rate debt', Journal of Finance 50, 789-819.

Merton, R., (1974): 'On the pricing of corporate debt: The risk structure of interest rates', Journal of Finance 29, 449-470.

Merton, R., (1973): 'Theory of Rational Option Pricing', The Bell Journal of Economics and Management Science 4(1), 141-183.

Myers, S., (1977): 'Determinants of Corporate Borrowing', Journal of Financial Economics, 5:147-75.

Myers, S. and Rajan, R. (1998). 'The Paradox of Liquidity'. Quarterly Journal of Economics, August 1998.

Plantin, G. (2004): ‘Tranching', working paper.

Schwarcz, S. (1993): Structured Finance: A Guide to the Principles of Asset Securitization, $2^{\text {nd }}$ ed. NY: Practicing Law Institute.

Schwarcz, S. (1993): 'The Alchemy of Asset Securitization', Stanford Journal of Law, Business and Finance, 1:133-54.

Skarabot, J. (2001). ‘Asset Securitization and Optimal Asset Structure of the Firm’. Mimeo.

Standard \& Poor's (2004): 'Research: Ratings and Surveillance Process in European Corporate Securitisations', London.

Winton, A. (1995): 'Costly State verification and Multiple Investors: the Role of Seniority', Review of Financial Studies, vol. 8, no. 1 (Spring 1995), p. 91-123. 